\title{
Radiation induces acid tolerance of Clostridium tyrobutyricum and enhances bioproduction of butyric acid through a metabolic switch
}

\author{
Xiang Zhou ${ }^{1 *+}$, Xi-Hong Lu ${ }^{1+}$, Xue-Hu Li ${ }^{1+}$, Zhi-Jun Xin ${ }^{1 \dagger}$, Jia-Rong Xie ${ }^{2 \dagger}$, Mei-Rong Zhao ${ }^{1}$, Liang Wang ${ }^{1}$, \\ Wen-Yue $\mathrm{Du}^{1}$ and Jian-Ping Liang ${ }^{1 *}$
}

\begin{abstract}
Background: Butyric acid as a renewable resource has become an increasingly attractive alternative to petroleumbased fuels. Clostridium tyrobutyricum ATCC $25755^{\top}$ is well documented as a fermentation strain for the production of acids. However, it has been reported that butyrate inhibits its growth, and the accumulation of acetate also inhibits biomass synthesis, making production of butyric acid from conventional fermentation processes economically challenging. The present study aimed to identify whether irradiation of $C$. tyrobutyricum cells makes them more tolerant to butyric acid inhibition and increases the production of butyrate compared with wild type.

Results: In this work, the fermentation kinetics of C. tyrobutyricum cultures after being classically adapted for growth at 3.6, 7.2 and $10.8 \mathrm{~g} \cdot \mathrm{L}^{-1}$ equivalents were studied. The results showed that, regardless of the irradiation used, there was a gradual inhibition of cell growth at butyric acid concentrations above $10.8 \mathrm{~g} \cdot \mathrm{L}^{-1}$, with no growth observed at butyric acid concentrations above $3.6 \mathrm{~g} \cdot \mathrm{L}^{-1}$ for the wild-type strain during the first $54 \mathrm{~h}$ of fermentation. The sodium dodecyl sulfate polyacrylamide gel electrophoresis also showed significantly different expression levels of proteins with molecular mass around the wild-type and irradiated strains. The results showed that the proportion of proteins with molecular weights of 85 and $106 \mathrm{kDa}$ was much higher for the irradiated strains. The specific growth rate decreased by $50 \%$ (from 0.42 to $0.21 \mathrm{~h}^{-1}$ ) and the final concentration of butyrate increased by $68 \%$ (from 22.7 to $33.4 \mathrm{~g}^{-1} \mathrm{~L}^{-1}$ ) for the strain irradiated at $114 \mathrm{AMeV}$ and $40 \mathrm{~Gy}$ compared with the wild-type strains.
\end{abstract}

Conclusions: This study demonstrates that butyric acid production from glucose can be significantly improved and enhanced by using ${ }^{12} \mathrm{C}^{6+}$ heavy ion-irradiated C. tyrobutyricum. The approach is economical, making it competitive compared with similar fermentation processes. It may prove useful as a first step in a combined method employing long-term continuous fermentation of acid-production processes.

Keywords: Acid inhibition, Butyrate, Clostridium tyrobutyricum, ${ }^{12} \mathrm{C}^{6+}$ heavy ion, Fermentation, Irradiation

\section{Background}

The trends of globalization and population expansion, in addition to technological advances, have led to skyrocketing energy demands worldwide [1]. The annual oil consumption, currently at around 32 billion barrels, continues to rise at the rate of population growth - about $1 \%$ a year (chart by Morgan Downey). As oil prices remain high, there are once again murmurs of anticipated

\footnotetext{
* Correspondence: syannovich@gmail.com; liangjp@hotmail.com

'Equal contributors

'Institute of Modern Physics, Chinese Academy of Sciences, 509 Nanchang Road, Lanzhou, Gansu 730000, PR China

Full list of author information is available at the end of the article
}

doom from various quarters. This is reflected in the transportation industry where increased demand and a limited supply of fuel have resulted in vastly inflated prices. While more oil deposits will likely be identified in the future, the fact remains that oil is a non-renewable resource that will eventually run out. Thus, the use of various kinds of renewable energy sources is of interest throughout the world.

The consumers' preference is for bio-based natural ingredients as additives for increasing fruit fragrance and aromatic compounds for production of perfumes [2-6]. Butyric acid is a short-chain fatty acid produced from 
sugars by Clostridia species such as Clostridium tyrobutyricum, C. beijerinckii, C. butyricum, C. populeti sp., C. thermobutyricum sp. nov. and C. acetobutyricum. Currently, the most promising microorganism used for the bioproduction of butyric acid is $C$. tyrobutyricum ATCC $25755^{\mathrm{T}}$ [7-10]. The microorganism is a Gram-positive, rod-shaped, spore-forming, obligate anaerobic bacterium. Its main fermentation products are butyric acid, acetate, n-butanol, acetic acid, hydrogen and carbon dioxide from various carbohydrates including glucose, $x y-$ lose, fructose, disaccharides, sucrose and lactose [11-16]. This strain is known to produce $\mathrm{CO}_{2}$ and hydrogen and grows well at $\mathrm{pH} 6.0$ and $37^{\circ} \mathrm{C}$ [17-19]. It is known that phosphotransacetylase Clostridium can utilize various polymeric substrates, including cellulose and galactan, with very little production of unnecessary materials [20-22]. In addition to its industrial use as a chemical feedstock, butyric acid has recently drawn strong interest as a precursor for biobutanol production via bioconversion [23,24]. Biobutanol (108.46 British thermal units per gallon) is a next-generation biofuel, primarily as a petroleum derivative, because of its low vapor pressure, high energy content and similar energy content to gasoline [25-28]. Butyrate can also be bioconverted to butanol by the fermentation action of certain strains of bacteria [29-31]. Moreover, biobutanol, like other biofuels, has many advantages, including that it is more economical, renewable, environmentally friendly and carbon neutral [32-34]. Normally, butyric acid is produced through the oxosynthesis of butyraldehyde from propylene [35-37]. However, the chemical synthesis of butyric acid is not attractive or sustainable because the raw materials are obtained from fossil fuels [38,39].

As such, butyrate fermentation is an alternative method for producing butyrate [40-44]. C. tyrobutyricum ATCC $25755^{\mathrm{T}}$ has been extensively studied for its ability to produce butyric acid and hydrogen [45-50]. There has been increasing interest in the production of butyric acid from agricultural commodities and processing wastes using $C$. tyrobutyricum ATCC 25755 [51-53]. The metabolic pathway for butyric acid fermentation of glucose, pentose, xylose and hexose in acidogenic C. tyrobutyricum ATCC 25755 has several possible end-products, including butyrate, with acetate, $\mathrm{CO}_{2}, \mathrm{H}_{2}$ and lactate as its main fermentation byproducts. Two analogous pathways lead to the formation of acetate and butyrate, with acetyl-coenzyme A (CoA) and butyryl-CoA functioning as key intermediates, respectively. First, acetyl phosphate and butyryl phosphate are produced from their CoA derivatives, catalyzed by phosphotransacetylase (PTA) and phosphotransbutyrylase (PTB), respectively. Then these acyl phosphates are converted to acetate and butyrate, catalyzed by acetate kinase (AK) and butyrate kinase (BK), respectively $[18,48,54]$. However, conventional butyric acid fermentation biotechnology is not yet economically competitive. For instance, a number of studies have shown that the butyrate yield is only 0.8 to $1.1 \mathrm{~mol} \cdot \mathrm{mol}^{-1}$ of fermented glucose, pentose, xylose and hexose, and the acetate yield is only 0.32 to $0.42 \mathrm{~mol} \cdot \mathrm{mol}^{-1}[4,24,55-58]$.

Strain improvement by mutagenesis and selection is a highly developed technique that plays a central role in the commercial development of microbial fermentation processes. The Heavy Ion Research Facility in Lanzhou (HIRFL) is committed to finding solutions to real problems through basic research. HIRFL comprises a superconducting Electron Cyclotron Resonance ion source, the $1.7 \mathrm{~m}$ Sector Focused Cyclotron $(K=69)$, the large SectorSeparated Cyclotron $(K=450)$, the Cooler-Storage Main Ring (CSRm) and the Cooler-Storage Experimental Ring of the newly built Cooler-Storage Ring, the radioactive ion beam lines (Radioactive Isotope Beam Line in Lanzhou RIBLL1 and RIBLL2) and experimental terminals. It is capable of providing ion beams from protons to uranium with energies of up to $2,800 \mathrm{MeV} \mathrm{u}^{-1}$ and 1,000 $\mathrm{MeV} \mathrm{u}^{-1}$ for protons and heavy ions, respectively. Mutagenic procedures can be carried out by varying the type of mutagen and dose to obtain mutant types that may be screened for improved activity [59-61]. At present, not only have mutagenic sources such as neutrons, UV light, $\alpha$-rays, $\gamma$-rays and lasers been developed and successfully employed to acquire various sorts of valuable strains, but novel sources are still under development with the aim to obtain a wider mutation spectrum and a higher ratio of mutation [62-67]. In recent years, the term irradiation technology has also been used to refer to novel techniques such as ${ }^{12} \mathrm{C}^{6+}$-ion irradiation. Specifically, ${ }^{12} \mathrm{C}^{6+}$-ion beam irradiation is a type of high linear energy transfer irradiation that is used to bombard the target with higher energy than can be achieved using different linear energy transfer forms of irradiation [68-71]. However, linear energy transfer, energy, and radiation dose may play a more fundamental role in regulating the synthesis and secretion of microbial biofuels.

To the best of our knowledge, measurements of the butyric acid levels produced by $C$. tyrobutyricum ATCC 25755 strains as a result of combined ${ }^{12} \mathrm{C}^{6+}$-ion beam radiation and fermentation have not been reported. The main objective of this study was to evaluate and characterize these C. tyrobutyricum mutants for their ability to produce butyric acid from glucose as a carbon source. In this work, the kinetics of cell growth and butyrate/butyric production in culture fermentation by mutant and wild-type C. tyrobutyricum were studied and compared.

\section{Results and discussion}

\section{Cell survival after irradiation}

Investigation of radiation-induced cell growth and death, defined as the time period required for a complete loss 
of the proliferation capacity or exaltation of the proliferation capacity, is one of the most commonly and reliably used methods to study radiation effects on cells. For the irradiation experiments, our laboratory verified that the 3-(4,5-dimethylthiazol-2-yl)-2,5-diphenyltetrazolium bromide (MTT) readings were proportional to the number of cells in vitro, at least in the phase of exponential growth (data not shown). ${ }^{12} \mathrm{C}^{6+}$ ion irradiation at high energy usually results in the death of the vast majority of cells. The fraction of cell death in the lag phase after irradiation and changes in doubling-time can be measured by assaying at various time points after irradiation. Because our assay was not only a single-point determination of survival, information about growth performance could also be acquired easily. The survival curve was drawn on a natural logarithmic scale of the survival fraction versus different physical parameters.

C. tyrobutyricum 25755 cells were irradiated $20 \mathrm{~h}$ after seeding. The strains with the lowest metabolic activity and slowest proliferation or cells that ceased to proliferate were excluded from the assay by washing and trypsinization when the plating was done after irradiation. The survival fraction as obtained from Equation (1) was compared with a representative set of experimental data. Figure 1 shows a comparison of the survival curves after
${ }^{12} \mathrm{C}^{6+}$-ion irradiation at different beam energies for the various strains of $C$. tyrobutyricum ATCC 25755. The results of the MTT assay are plotted against the irradiation dose $(10$ to $50 \mathrm{~Gy})$ at $68 \mathrm{AMeV}$ of energy and $10^{6}$ to $10^{8}$ ions $\cdot$ pulse $^{-1}$ levels, which were $e^{0} \rightarrow e^{-4.5}$ for Figure 1A, $e^{0} \rightarrow e^{-5.8}$ for Figure $1 \mathrm{~B}$ and $e^{0} \rightarrow 0$ for Figure $1 \mathrm{C}$. Figure 1D-F shows the cellular survival data from the results of the MTT assay against the irradiation dose (10 to $50 \mathrm{~Gy})$ at $114 \mathrm{AMeV}$ of energy and $10^{6}$ to $10^{8}$ of ions.pulse $e^{-1}$ levels, which were $e^{O} \rightarrow 0$. In general, sufficient agreement between the calculations and experimental data was obtained. For the strains treated at $68 \mathrm{AMeV}$, the equation underestimated the effectiveness of the dose, whereas for the cells irradiated at high energies (114 AMeV), the result was overestimated. The maximal deviation, derived from the ratio of calculated to measured doses for a given effect level, was $15 \%$. The survival fraction of the strains strongly depended on the particular physical characteristics of the ${ }^{12} \mathrm{C}^{6+}$-ion beam, as determined by the energy, dose and ions $\cdot$ pulse $^{-1}$ levels of the particles under consideration (Figure 1). Obviously, the survival fraction decreased with increasing carbon ion energy. As expected, the survival logarithmic of the assays showed the same characteristics: the survival depended on the energy, ions.pulse ${ }^{-1}$ and

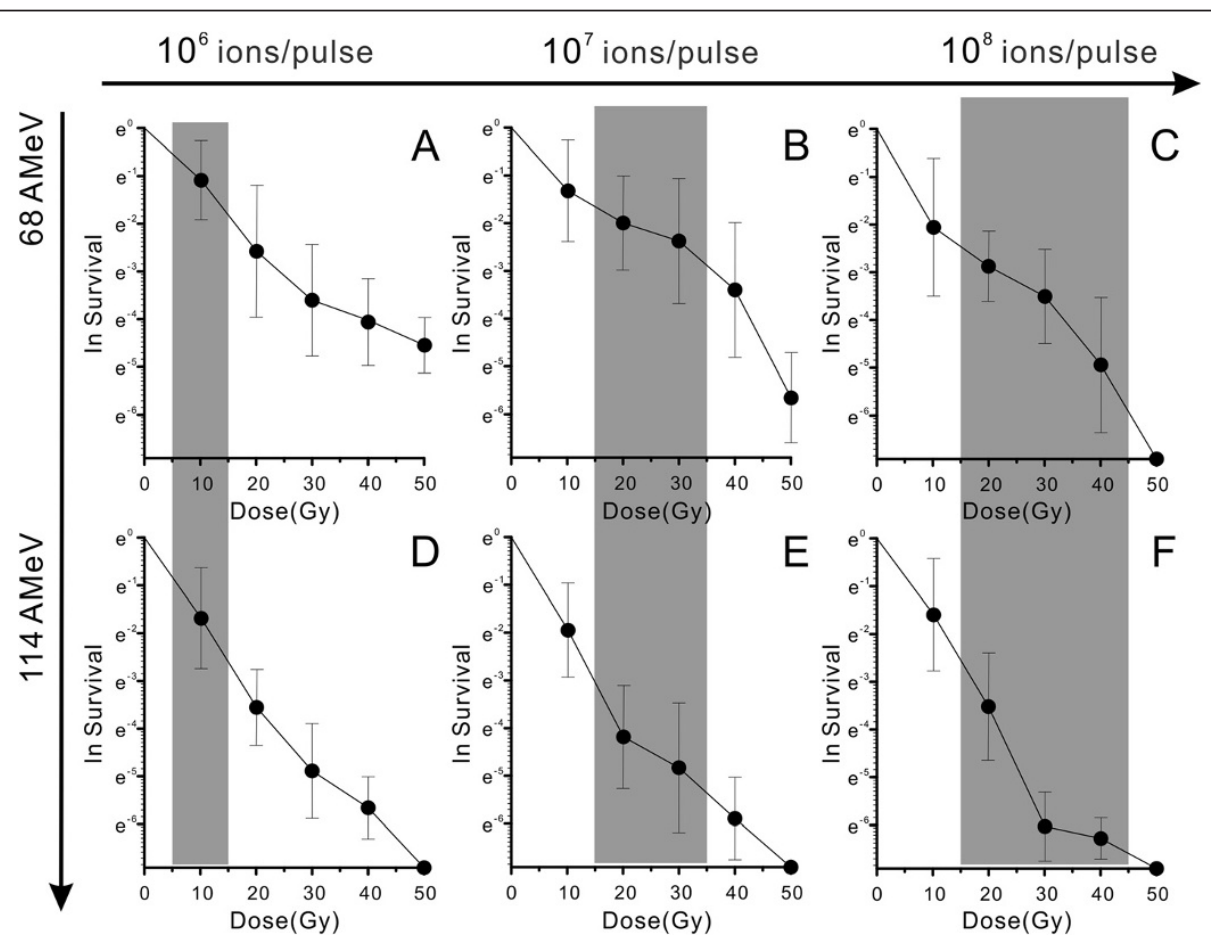

Figure 1 The effect of ${ }^{12} \mathrm{C}^{6+}$-ion irradiation on the survival of Clostridium tyrobutyricum ATCC 25755 . The cells were irradiated $20 \mathrm{~h}$ after seeding and the extent of survival was determined by MTT assay. Survival data is plotted against the irradiation levels. $(\mathbf{A}-\mathbf{C}){ }^{12} \mathrm{C}^{6+}$-ions were accelerated up to $68 \mathrm{AMeV}$, and their ions/pulse ranged from $10^{6}$ to $10^{8}$, at a dose rate of 10 to $50 \mathrm{~Gy}$. (D-F) ${ }^{12} \mathrm{C}^{6+}$-ions were accelerated up to $114 \mathrm{AMeV}$, and their ions/pulse ranged from $10^{6}$ to $10^{8}$, at a dose rate of 10 to $50 \mathrm{~Gy}$. Cells with low metabolic activity and slow proliferation or cells that cease to proliferate were excluded from the assay by washing and trypsinization when the plating was done after irradiation. 
(See figure on previous page.)

Figure 2 Time-course of the activities of wild-type and irradiated cells as a function of added butyric acid concentrations during the first $\mathbf{5 4} \mathbf{~ h}$ of fermentation. (A) Cell growth of the wild-type strains, unaffected by the addition of butyrate (control cultures). (B-D) Cell growth of the irradiated strains (energy 68 AMeV and doses of 20, 30 and 40 Gy), unaffected by the addition of butyrate (control cultures). (E,F) Cell growth of the irradiated strains (energy $114 \mathrm{AMeV}$ and doses of 20, 30 and 40 Gy), unaffected by the addition of butyrate (control cultures). (A1-A3) The effects of added butyrate on wild-type cell growth. Individual batch cultures were carried out in chemically defined P2-medium (performed in serum bottles) containing glucose (approximately $42 \mathrm{~g} \cdot \mathrm{L}^{-1}$ ) and supplemented with 3.6 (A1), 7.2 (A2) and $10.8 \mathrm{~g} \cdot \mathrm{L}^{-1}$ (A3) of butyric acid. (B1-B3, C1-C3, D1-D3) The effect of added butyrate on the growth of the irradiated cells (energy 114 AMeV and doses of 20,30 and $40 \mathrm{~Gy}$ ). Individual batch cultures were carried out in chemically defined P2-medium (performed in serum bottles) containing glucose (approximately $42 \mathrm{~g} \cdot \mathrm{L}^{-1}$ ) and supplemented with $3.6(\mathrm{X} 1), 7.2$ (X2) and $10.8 \mathrm{~g} \cdot \mathrm{L}^{-1}$ (X3) of butyric acid. (E1-E3, F1-F3, G1-G3) The effects of added butyrate on the growth of the irradiated cells (energy $114 \mathrm{AMeV}$ and doses of 20,30 and $40 \mathrm{~Gy}$ ). Individual batch cultures were carried out in chemically defined

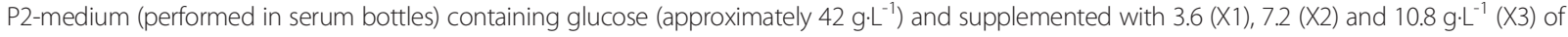
butyric acid.

dose of ${ }^{12} \mathrm{C}^{6+}$-ion irradiation. The increase of one physical parameter at a time led to a decrease in survival rate. Very limited survival $\left(e^{-3.5} \rightarrow e^{-6.5}\right)$ was obtained when the ${ }^{12} \mathrm{C}^{6+}$-ion was irradiated using $114 \mathrm{AMeV}$ of energy, a 20 to 40 Gy dose and $10^{6}$ to $10^{8}$ ions.pulse ${ }^{-1}$.

Many cell types are characterized by regular cell division every 12 to $24 \mathrm{~h}$. Because of the power of exponential growth, a single cell can produce thousands of daughter cells within approximately 9 to 12 normal division cycles, that is, a few days. After irradiation, the survivors may then be composed of some mutants. A very small percentage of the C. tyrobutyricum ATCC 25755 survivors may show an improved ability to produce butyrate.

\section{The effects of butyric acid on cell growth following irradiation}

C. tyrobutyricum ATCC 25755 uses glucose or xylose as a carbon and energy source. The monosaccharide is transported into the cell via a phosphoenolpyruvate-dependent phosphotransferase uptake system. Thereafter, glucose or xylose is metabolized via glycolysis [72,73], which exhibits an insignificant $\mathrm{pH}$ dependence in the range $\mathrm{pH} 7$ to $\mathrm{pH}$ 5.5. However, the fermentations were stopped when glucose or xylose was no longer consumed by the cells because of inhibition by butyrate. To further investigate the specific effect of irradiation on the cell growth profiles (based on measurements of the optical density (OD) of cell suspension at $600 \mathrm{~nm}$ ), individual batch cultures were carried out in chemically defined P2-medium (performed in serum bottles) containing $42 \mathrm{~g} \cdot \mathrm{L}^{-1}$ of glucose and supplemented with $3.6,7.2$ and $10.8 \mathrm{~g} \cdot \mathrm{L}^{-1}$ of butyric acid. The $\mathrm{pH}$ of the culture of $C$. tyrobutyricum ATCC 25755 (Figure 2A, control) dropped to around $4.8(\Delta \mathrm{pH}$ of 1.4 , from $\mathrm{pH}$ 6.2) compared with when it was supplemented with $3.6 \mathrm{~g} \cdot \mathrm{L}^{-1}$ of butyric acid (Figure 2A1), $7.2 \mathrm{~g} \cdot \mathrm{L}^{-1}$ of butyric acid (Figure 2A2) and $10.8 \mathrm{~g} \cdot \mathrm{L}^{-1}$ of butyric acid (Figure 2A3), the corresponding $\mathrm{pH}$ values were about 6.0 $(\Delta \mathrm{pH}$ of 0.5 starting from 6.5$), 6.1(\Delta \mathrm{pH}$ of 0.3 starting from 6.4) and $5.9(\Delta \mathrm{pH}$ of 0.5 starting from 6.4), respectively. However, when the culture was irradiated with 68
$\mathrm{AMeV}$ at a dose of $40 \mathrm{~Gy}$ (Figure 2D, control), the $\mathrm{pH}$ dropped to around $4.8(\Delta \mathrm{pH}$ of 1.7 starting from 6.5$)$ while at a dose of 40 Gy (supplemented with $3.6 \mathrm{~g} \cdot \mathrm{L}^{-1}$ of butyric acid) (Figure 2D1), a dose of 40 Gy (supplemented with $7.2 \mathrm{~g} \cdot \mathrm{L}^{-1}$ of butyric acid) (Figure 2D2) and a dose of $40 \mathrm{~Gy}$ (supplemented with $10.8 \mathrm{~g} \cdot \mathrm{L}^{-1}$ of butyric acid) (Figure 2D3), the $\mathrm{pH}$ values were about $4.6(\Delta \mathrm{pH}$ of 1.6 starting from 6.2$), 4.8(\Delta \mathrm{pH}$ of 1.4 starting from 6.2$)$ and $5.9(\Delta \mathrm{pH}$ of 0.3 starting from 6.2$)$, respectively. When the culture was irradiated at $114 \mathrm{AMeV}$ and a dose of $40 \mathrm{~Gy}$ (Figure 2G, control), the $\mathrm{pH}$ dropped to around $5.7(\Delta \mathrm{pH}$ of 0.6 starting from 6.3) while at a dose of 40 Gy (supplemented with $3.6 \mathrm{~g} \cdot \mathrm{L}^{-1}$ of butyric acid) (Figure $2 \mathrm{G} 1$ ), a dose of 40 Gy (supplemented with $7.2 \mathrm{~g} \cdot \mathrm{L}^{-1}$ of butyric acid) (Figure 2G2) and a dose of 40 Gy (supplemented with $10.8 \mathrm{~g} \cdot \mathrm{L}^{-1}$ of butyric acid) (Figure $2 \mathrm{G} 3$ ), the $\mathrm{pH}$ values were about $5.7(\Delta \mathrm{pH}$ of 0.6 starting from 6.3$), 5.4(\Delta \mathrm{pH}$ of 0.9 starting from 6.3$)$ and $5.6(\Delta \mathrm{pH}$ of 0.7 starting from 6.3 ), respectively. When the culture was irradiated at $68 \mathrm{AMeV}$ and a dose of 20 Gy (supplemented with $7.2 \mathrm{~g} \cdot \mathrm{L}^{-1}$ of butyric acid) (Figure 2B2), the $\mathrm{pH}$ dropped to around 4.4 ( $\Delta \mathrm{pH}$ of 0.9 starting from 6.3 ) while at a dose of $30 \mathrm{~Gy}$ (supplemented with $7.2 \mathrm{~g} \cdot \mathrm{L}^{-1}$ of butyric acid) (Figure $2 \mathrm{C} 2$ ) and a dose of 40 Gy (supplemented with $7.2 \mathrm{~g} \cdot \mathrm{L}^{-1}$ of butyric acid) (Figure 2D2), the $\mathrm{pH}$ values were about 4.6 $(\Delta \mathrm{pH}$ of 1.7 starting from 6.3$)$ and $4.8(\Delta \mathrm{pH}$ of 1.5 starting from 6.3), respectively. When the culture was irradiated at $114 \mathrm{AMeV}$ and a dose of $40 \mathrm{~Gy}$ (supplemented with $10.8 \mathrm{~g} \cdot \mathrm{L}^{-1}$ of butyric acid) (Figure 2E3), the $\mathrm{pH}$ decreased to $5.9(\Delta \mathrm{pH}$ of 0.4 starting from 6.3$)$ while at a dose of 30 Gy (supplemented with $10.8 \mathrm{~g} \cdot \mathrm{L}^{-1}$ of butyric acid) (Figure 2F3) and a dose of 40 Gy (supplemented with $10.8 \mathrm{~g} \cdot \mathrm{L}^{-1}$ of butyric acid) (Figure $2 \mathrm{G} 3$ ), the $\mathrm{pH}$ values were about $6.0(\Delta \mathrm{pH}$ of 0.3 starting from 6.3$)$ and $5.8(\Delta \mathrm{pH}$ of 0.5 starting from 6.3 ), respectively.

These differences in $\mathrm{pH}$ regulate the temporal switch associated with solvent formation for each irradiated strain. This suggests that the wild-type and irradiated strains exhibited a biphasic metabolic pattern strongly influenced by the $\mathrm{pH}$ of the medium. As a general trend, the cells initially consumed glucose to support growth 
and produce and excrete organic acids (butyrate and acetate) as primary metabolites (acidogenesis), which caused a decrease in the medium $\mathrm{pH}$ when they accumulated to certain levels. This increase in broth acidity shifted the formation of acids towards the production of solvents when the culture reached the stationary phase of cell growth (solventogenesis). At high $\mathrm{pH}$, organic acids are mainly formed, whereas at low $\mathrm{pH}$, solvent production is stimulated. As expected, the nature of the metabolic shift and the kinetic pattern of solvent formation were strain dependent, given that irradiated strains exhibited their own intrinsic genetic and metabolic characteristics. Butyric acid has previously been reported to inhibit cell growth [74]. The results showed that in the wild-type strains, there was a gradual inhibition of cell growth, with no realistic growth observed at butyric acid concentrations above $3.6 \mathrm{~g} \cdot \mathrm{L}^{-1}$. However, in the irradiated strains, there was no gradual inhibition of cell growth, and no realistic growth was observed for butyric acid concentrations above $10.8 \mathrm{~g} \cdot \mathrm{L}^{-1}$.

To examine in more detail the effect of added butyrate, the cell growth profiles (based on OD measurements) for the wild-type strains and irradiated strains were compared (Figure 2A1-G3) during the first $54 \mathrm{~h}$ of fermentation. Interestingly, the butyric acid tolerance of strains was greatly enhanced when the energy and dose of ${ }^{12} \mathrm{C}^{6+}$-ion irradiation was increased. The metabolic pathways of glucose metabolism in C. tyrobutyricum ATCC 25755 are shown in Figure 3. The acetyl-CoA, acetoacetyl-CoA and butyryl-CoA are three key intermediates, and are of

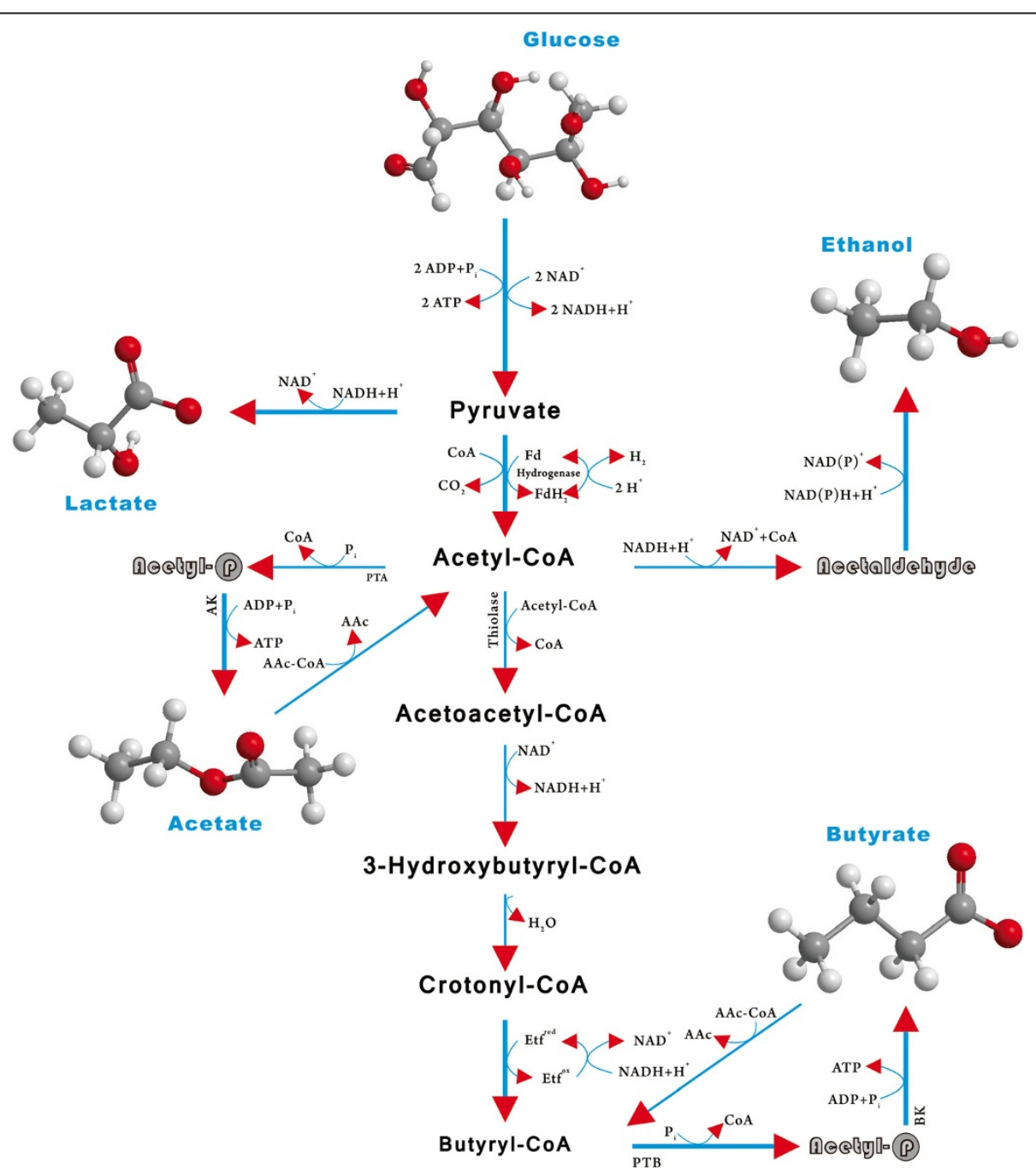

Figure 3 Metabolic pathways of glucose metabolism in Clostridium tyrobutyricum. Enzymes are indicated by letters as follows: lactate dehydrogenase; pyruvate-ferredoxin oxidoreductase; NADH-ferredoxin oxidoreductase; NADPH-ferredoxin oxidoreductase; hydrogenase; phosphate acetyltransferase (phosphotransacetylase); acetate kinase; acetaldehyde dehydrogenase; ethanol dehydrogenase; thiolase (acetyl-CoA acetyltransferase); acetoacetyl-CoA; acetate/butyrate:CoA transferase; acetoacetate decarboxylase; 3-hydroxylbutyryl-CoA dehydrogenase; crotonase; butyryl-CoA dehydrogenase; phosphate butyltransferase (phosphobutyrylase); butyrate kinase. 
particular interest for fermentation with respect to the potential for formation of different products during acidogenesis or solventogenesis. These intermediates are important branch points that direct the metabolic flow either to acid or to solvent formation. As the last key intermediate, butyryl-CoA initiates the formation of butyric acid/ butyrate. Butyrate is produced by the sequential activities of PTB, and BK $[75,76]$. Both enzymes are most active during acidogenesis and their specific activities decline during solventogenesis, two-fold for PTB and six-fold for Buk [76,77]. Usually a strong $\mathrm{pH}$-dependent activity with an in vitro optimum at acidogenic $\mathrm{pH}$ levels of $\mathrm{pH} 5.5$ (optimal around $\mathrm{pH} 4.7$ ) and an in vivo (endogenous) $\mathrm{pH}$ greater than 5.5 are required to induce solventogenesis.
Yet, a comparative analysis of these plots clearly revealed one major cluster composed of the strains irradiated at 68 $\mathrm{AMeV}$ and $40 \mathrm{~Gy}$ and the strains irradiated at $114 \mathrm{AMeV}$ and doses of 30 and $40 \mathrm{~Gy}$. The two groups showed a very similar overall tolerance to increasing butyrate concentrations when compared with the wild-type bacteria.

\section{Effect of ${ }^{12} \mathrm{C}^{6+}$ ion irradiation on butyric acid production}

The butyric acid production of the irradiated strains was greatly improved in terms of both the final product concentration and yield compared with the wild-type strain as shown in Figure 4B,E. The non-irradiated (wild-type strain, control) C. tyrobutyricum culture inoculated into glucose-minimal media started to consume sugar almost
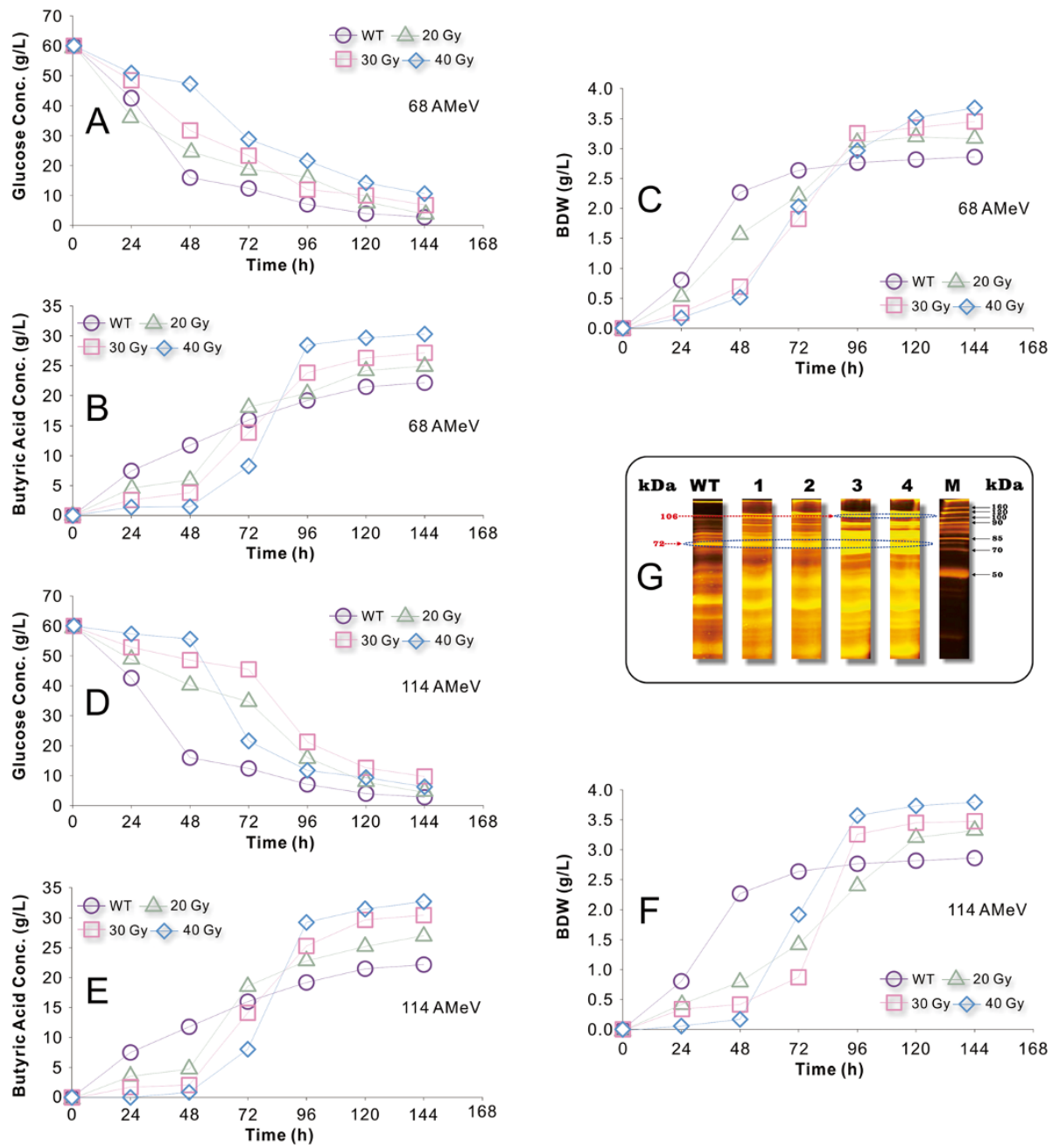

Figure 4 Comparison of acid and biomass dry weight production of wild-type and irradiated C. tyrobutyricum grown on glucose (containing $60 \mathrm{~g} \cdot \mathrm{L}^{-1}$ ) in clostridial growth medium at $37^{\circ} \mathrm{C}$ at pH 5.5 and 6.0. (A-C) Impact of ${ }^{12} \mathrm{C}^{6+}$-ion irradiation (energy $68 \mathrm{AMeV}$ and doses of 20,30 and $40 \mathrm{~Gy}$ ) on glucose concentration, butyric acid production and biomass dry weight. (D-F) Impact of ${ }^{12} \mathrm{C}^{6+}$-ion irradiation (energy $114 \mathrm{AMeV}$ and doses of 20,30 and $40 \mathrm{~Gy}$ ) on glucose concentration, butyric acid production and biomass dry weight. (G) SDS-PAGE of cellular proteins from C. tyrobutyricum. Lane WT: wild type; lane 1: cells irradiated at $68 \mathrm{AMeV}$ and a dose of $30 \mathrm{~Gy}$; lane 2: cells irradiated at 68 $\mathrm{AMeV}$ and a dose of $40 \mathrm{~Gy}$; lane 3: cells irradiated at $114 \mathrm{AMeV}$ and a dose of $30 \mathrm{~Gy}$; lane 4: wild type and cells irradiated at $114 \mathrm{AMeV}$ and a dose of $40 \mathrm{~Gy}$; lane MW: protein molecular weight markers. 
immediately, with butyric acid production beginning 12 to $18 \mathrm{~h}$ later (Figure 4A,B). The same control culture inoculated into clostridial growth medium (CGM) containing $60 \mathrm{~g} \cdot \mathrm{L}^{-1}$ glucose required over $96 \mathrm{~h}$ to acclimate despite the fact that the irradiated strains and wild-type strain fermentations were tested under the same conditions. The extended period of minimal metabolism and productivity is because the radiation (different parameters) caused a delay in the log phase of cellular growth (Figure 4C,F). The butyric acid tolerance of the irradiated strains was greatly enhanced, allowing them to produce more butyric acid, resulting in complete glucose utilization and production of over $32 \mathrm{~g} \cdot \mathrm{L}^{-1}$ of butyric acid and similar levels of cell biomass. Furthermore, the butyric acid/control ratio increased from 1.0 for the wild-type strain to 1.52 for the strains irradiated at 114 $\mathrm{AMeV}$ and $40 \mathrm{~Gy}, 1.37$ for the strains irradiated at 114 $\mathrm{AMeV}$ and $30 \mathrm{~Gy}, 1.41$ for the strains irradiated at $68 \mathrm{AMeV}$ and $40 \mathrm{~Gy}$, and 1.31 for the strains irradiated at $68 \mathrm{AMeV}$ and $30 \mathrm{~Gy}$. This trend indicates that the carbon and energy flux were redistributed in the metabolic pathways of the irradiated strains, which also resulted in significant changes in the production of various fermentation products. It should be noted that the acetic acid production (data not shown) leveled off much sooner than butyrate/butyric during the fermentation. The fermentations stopped when glucose was no longer consumed by the cells because of an accumulation of organic acids and waste products in the broth, which caused inhibition of cell growth and other activities. However, the irradiated strains were more tolerant to butyric acid, as indicated by the much higher final butyrate concentration attained in the fermentations with these irradiated strains compared with the wild-type. This is not altogether surprising; as shown in Figure 3, the increased butyric acid tolerance of the irradiated strains may also be attributed to the reduced flux through the butyrate PTA/AK pathway. Since the irradiated strains were no longer dependent on the PTA/AK pathway for energy production and survival, they became less sensitive to butyric acid inhibition $[11,18]$.

Induction of the ack and pta genes, which encode enzymes associated with the acetate formation pathway, significantly improve butyric acid production [76-78]. To better understand the fermentation kinetics of glucose metabolism after exposure of $C$. tyrobutyricum to ${ }^{12} \mathrm{C}^{6}$ ${ }^{+}$-ion irradiation and the resulting damage to the ack and pta genes, the protein expression of wild-type and irradiated strains were studied and compared. Figure 4G shows the results from SDS-PAGE. Analysis confirmed the expression of the protein (molecular weight, approximately $85 \mathrm{kDa}$ ) in four irradiated strains, with the highest protein expression level in lane 4. The amount of an approximately $106 \mathrm{kDa}$ protein was much higher for the strain irradiated at $114 \mathrm{AMeV}$ and $40 \mathrm{~Gy}$ than the wild-type strain. AK and PTA from several microorganisms have been characterized, but the results showed large variations in their molecular weight [77]. Enzyme activity assays were thus carried out to further study the roles of AK, PTA and PTB in the acid-forming pathways (Figure 3). The metabolic selectivity in C. tyrobutyricum is influenced by growth stage, with exponentially growing cultures producing both butyric and acetic acids, whereas slower stationary growth rates tend to produce butyric acid $[3,78,79]$. As such, during the log phase growth of each batch, culture samples were removed and analyzed for the activities of PTA, PTB and AK in the irradiated and wild-type strains. The specific enzyme activities for PTA, PTB and AK in the irradiated strains (different physical parameters) were assayed and their relative activities were compared with those of the wildtype strain. The AK activity was reduced by approximately $47 \%$ for the strains irradiated at $114 \mathrm{AMeV}$ and $40 \mathrm{~Gy}, 31 \%$ for the strains irradiated at $114 \mathrm{AMeV}$ and $30 \mathrm{~Gy}$ and $26 \%$ for the strains irradiated at $68 \mathrm{AMeV}$ and 40 Gy. Compared with the wild-type strains, the strains irradiated at $114 \mathrm{AMeV}$ and $40 \mathrm{~Gy}$ had a lower AK activity (47\%) but unexpectedly higher PTA activity (129\%), although similar PTB activities. Because the strains irradiated at $114 \mathrm{AMeV}$ had much lower AK activity, the PTA-AK pathway would have been impaired and, thus, they produced more butyrate $\left(60 \mathrm{~g} \cdot \mathrm{L}^{-1}\right)$ from glucose than the wild-type strains. As mentioned earlier, these enhancements and improvements can be attributed to an enhanced tolerance to butyrate inhibition and to some extent the reduced carbon flux through the PTA-AK pathway as evidenced by the increased butyrate/acetate ratio in the irradiated strains.

\section{Effect of ${ }^{12} \mathrm{C}^{6+}$ irradiation on acid yield and growth of C. tyrobutyricum}

An experiment was conducted in fermentation mode using glucose as the primary carbon source in order to determine the butyrate production capacity of C. tyrobutyricum ATCC 25755 after irradiation. As can be seen in Figure 5A,B, the butyric acid yield from glucose increased significantly, from $0.43 \mathrm{~g} \cdot \mathrm{g}^{-1}$ for the wild-type strains to $0.56 \mathrm{~g}^{-\mathrm{g}^{-1}}$ for the strain irradiated at $68 \mathrm{AMeV}$ and a dose of $30 \mathrm{~Gy}, 0.59 \mathrm{~g} \cdot \mathrm{g}^{-1}$ for the strain irradiated at $68 \mathrm{AMeV}$ and a dose of $40 \mathrm{~Gy}, 0.63 \mathrm{~g} \cdot \mathrm{g}^{-1}$ for the strain irradiated at $114 \mathrm{AMeV}$ and a dose of $30 \mathrm{~Gy}$, and $0.66 \mathrm{~g} \cdot \mathrm{g}^{-1}$ for the strain irradiated at $114 \mathrm{AMeV}$ and a dose of $40 \mathrm{~Gy}$. It is of note that the butyrate yield for the strain irradiated at $114 \mathrm{AMeV}$ and a dose of $40 \mathrm{~Gy}$ would have been higher $\left(>0.66{\left.\mathrm{~g} \cdot \mathrm{g}^{-1}\right)}\right.$ if the glucose consumption during the lag phase was neglected. The acetic acid produced by the strain irradiated at $68 \mathrm{AMeV}$ and doses of 30 and 40 Gy were similar to that from the wild 

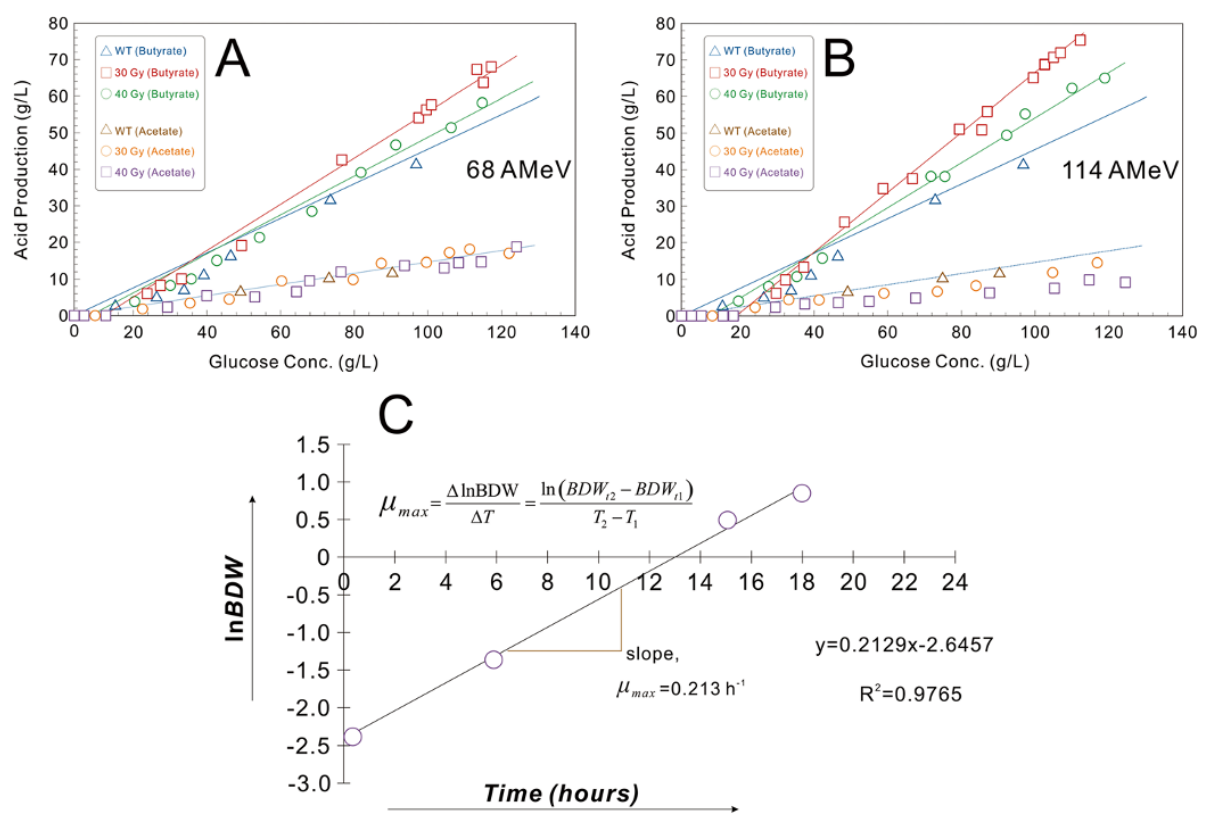

Figure 5 Comparison of acid production for the wild-type and irradiated C. tyrobutyricum cells. (A)The production of butyric acid and acetic acid were estimated from the slopes of the linear plots for the wild-type cells and the cells irradiated at 68 AMeV and doses of 30 and $40 \mathrm{~Gy}$. (B) The production of butyric acid and acetic acid were estimated from the slopes of the linear plots for the wild-type cells and the cells irradiated at $114 \mathrm{AMeV}$ and doses of 30 and $40 \mathrm{~Gy}$. (C) Linearization (integration) of the kinetic growth profiles of biomass dry weight over time using a natural logarithm transformation. The maximal specific growth rates for the wild-type and the irradiated cells were calculated according to the example given for the cells irradiated at $114 \mathrm{AMeV}$ and a dose of $40 \mathrm{~Gy}$ grown in Clostridium growth medium containing $60 \mathrm{~g} \cdot \mathrm{L}^{-1}$ of glucose. BDW, biomass dry weight.

type. However, the acetic acid produced by the strain irradiated at $114 \mathrm{AMeV}$ and doses of 30 and 40 Gy decreased compared with that of the wild type. As shown in Figure 5B, the acetic acid yield from glucose also decreased significantly, from approximately $0.11 \mathrm{~g} \cdot \mathrm{g}^{-1}$ for

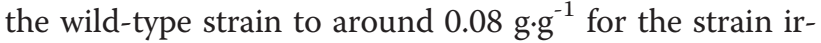
radiated at $114 \mathrm{AMeV}$ and $30 \mathrm{~Gy}$, and around $0.07 \mathrm{~g} \cdot \mathrm{g}^{-1}$ for the strain irradiated at $114 \mathrm{AMeV}$ and $40 \mathrm{~Gy}$. Nevertheless, the butyrate/acetate ratio $(\mathrm{g} / \mathrm{g})$ increased from 3.99 for the wild-type strain to 5.82 for the irradiated strains, a clear indication that the metabolic pathways in the irradiated strains were shifted to favor butyric acid production over acetic acid production. As shown in Figure 3, since AK and PTA activities were significantly reduced in the irradiated strains, more pyruvate must have been catabolized through the butyrate-producing pathway, leading to higher butyrate yields from glucose. In addition, the butyric acid could have also promoted an earlier shift to the acid-producing pathway, which might be reflected in a slower growth rate. For the same reason, the irradiated samples suffered from a slower growth rate because less ATP was produced from the acetate-producing (PTA-AK) pathway, which normally can generate more ATP per mole of glucose metabolized than the butyrate-producing (PTB-BK) pathway [36].
A plot of $\mu_{\max }$ was then determined at high concentrations of initial glucose $\left(40,60,80\right.$ and $\left.120 \mathrm{~g} \cdot \mathrm{L}^{-1}\right)$ by fitting the fermentation data to the predictions from the model simulation. Linearization (integration) of the kinetic growth profiles of biomass dry weight (BDW) over time were achieved by using the natural logarithm transformation:

$$
\begin{aligned}
x(t) & =x_{0} \cdot \exp (\mu) \rightarrow \ln x(t)=\mu \cdot t+\ln x_{0} \rightarrow y \\
& =m+b(\text { straight line equation }) .
\end{aligned}
$$

Where $x(t)=\mathrm{BDW}$ concentration at every time $x_{0} ; \mathrm{t}=$ initial BDW concentration; $\mu_{\max }=$ maximum specific growth rate $\left(\mathrm{h}^{-1}\right)$; and the specific growth rate is $\mu=(1 / x$ $(t)) \cdot(d x / d t)$. For simplification purposes, it was assumed that all bacteria followed the exponential law of cell growth in a batch culture according to a first-order kinetic model [80-82]. The specific growth rate of cells, or increase in cell mass over time, represents a shift in selectivity at different growth rates, which has a significant impact on the fermentation process [83]. Rapid cell growth has a higher energy demand and preferentially produces acetic acid. At low growth rates, the production of butyric acid is favored over acetic acid [84]. For continuous fermentation, the production of butyrate/ 
butyric acid is higher when $\mu$ is lower. When $\mu$ tends to zero, an oscillation in productivity occurs [85-88]. These equations allow a comparison of the growth rate of batch and continuous systems within the wild-type and the radiated strains.

The model is not media-independent: the media used as described above affects both the cell growth rate and the quantities of butyrate/butyric acid produced, and differing glucose consumption profiles would produce different results. To better quantify the optimal glucose concentration for the cell growth, the maximal specific growth rates were determined for the wild-type and irradiated strains from kinetic data taken from the exponential growth phase and plotted against the concentration of added glucose. As can be seen in Figure 5C, the maximal specific growth rates for the strains irradiated at $114 \mathrm{AMeV}$ and a dose of 40 Gy were calculated according to the example where the strain was grown in CGM medium containing $60 \mathrm{~g} \cdot \mathrm{L}^{-1}$ of glucose. The best linear range of data points was chosen that corresponded to the exponential growth phase of the strain. In some cases, where the minimum requirement of three experimental data points was not satisfied, an alternative expression was utilized that accounted only for two extreme points (at the beginning and at the end of the exponential phase). The straight line slope $\left(\mathrm{m}=\mu_{\max }\right)$ gives the maximal specific growth rate $\left(0.213 \mathrm{~h}^{-1}\right)$. The unary linear regression model $(y=0.2129 x-2.6457)$ had an adjusted determination coefficient of $R^{2}=0.9765$, indicating that all data points were included on the line of best fit and no data points varied from this line. Additionally, each specific growth rate was estimated from the slope of the corresponding semi-logarithmic plot of the BDW versus time. Error bars are expressed in terms of the standard deviation (SD) obtained from calculations of each independent fermentation replicate for the irradiated strains and wild type (the original data is not shown). The results demonstrate that these irradiated strains had a significantly lower specific growth rate $(\mu=$ $0.38 \pm 0.03$ to $0.21 \pm 0.02 \mathrm{~h}^{-1}$ ) as compared with the wild type $\left(\mu=0.38\right.$ to $0.42 \mathrm{~h}^{-1}$ ). The use of ${ }^{12} \mathrm{C}^{6+}$-ion irradiation at $68 \mathrm{AMeV}, 20$ to $40 \mathrm{~Gy}$ and $10^{6}$ to $10^{8}$ ions.pulse ${ }^{-1} \mathrm{re}-$ sulted in a particularly long lag phases of 10,12 and $16 \mathrm{~h}$, respectively. By comparison, the use of ${ }^{12} \mathrm{C}^{6+}$-ion irradiation at $114 \mathrm{AMeV}, 20$ to $40 \mathrm{~Gy}$ and $10^{6}$ to $10^{8}$ ions.pulse $\mathrm{e}^{-1}$ resulted in lag phases of 12,18 and $24 \mathrm{~h}$, respectively. These longer lag phases may be partially attributed to the different radiation parameters and the low density inoculation amount used in the fermentation. The lower specific growth rate for the irradiated cells may be a result of the metabolic burden placed on cells as a result of the lower amount of energy generated by glucose metabolism because of damage induced at higher energy and doses. Compared with the wild-type strains, the 20 and 30 Gy irradiated strains at $68 \mathrm{AMeV}$ had similar growth and glucose consumption profiles, with an almost identical specific growth rate of $\mu=0.42 \pm 0.03 \mathrm{~h}^{-1}$, whereas the 30 and 40 Gy irradiated strains at $114 \mathrm{AMeV}$ showed a significantly longer lag phase, slower glucose consumption, and a much lower specific growth rate of $\mu=0.26 \pm 0.03 \mathrm{~h}^{-1}$ (30 Gy) and $\mu=0.21 \pm 0.02 \mathrm{~h}^{-1}$ (40 Gy).

As noted earlier, acetate is synthesized via PTA and AK reactions with the latter reaction providing ATP (Figure 3). For the biosynthesis of butyrate, two molecules of acetylCoA are condensed to acetoacetyl-CoA, followed by a reduction to butyryl-CoA, which is then converted to butyrate via PTB and BK reactions with ATP generation. The lower specific growth rate for the irradiated strains (energy 114 AMeV and doses of 30 and 40 Gy) can be attributed to the metabolic burden on cells caused by less energy (ATP) generation during glucose metabolism because of irradiation damage of $a c k$ and pta. The BDW from glucose for the irradiated strains also varied from the wild-type strains. The plot of BDW versus time and specific growth rate of the irradiated strains indicated that the carbon and energy flux were redistributed throughout the metabolic pathways of these strains, which also resulted in significant changes in acid production of fermentation products.

\section{Conclusions}

Examination of the effect of ${ }^{12} \mathrm{C}^{6+}$ heavy ion irradiation on the fermentation performance of acid-producing C. tyrobutyricum ATCC $25755^{\mathrm{T}}$ strain was performed. Following irradiation, the presence of increasing butyrate concentrations in the media resulted in a gradual inhibition of cell growth for butyric acid concentrations above $10.8 \mathrm{~g} \cdot \mathrm{L}^{-1}$, with no realistic growth observed for butyric acid concentrations above $3.6 \mathrm{~g} \cdot \mathrm{L}^{-1}$ for the wild-type strains during the first $54 \mathrm{~h}$ of fermentation. The irradiated strains were shown to be tolerant to butyric acid inhibition. In addition, the specific growth rate decreased by $50 \%$ and the final concentration of butyrate increased by $68 \%$ when the strains were irradiated at $114 \mathrm{AMeV}$ and a dose of $40 \mathrm{~Gy}$ compared with the wild-type strains. This study demonstrates that butyric acid production from glucose can be significantly improved and enhanced by using ${ }^{12} \mathrm{C}^{6+}$ heavy ion irradiated $C$. tyrobutyricum. Future work includes adaptation of the concept of acetone-butanol-ethanol fermentation for use in a continuous fibrous-bed bioreactor by using ${ }^{12} \mathrm{C}^{6+}$ heavy ion irradiated Clostridium sp. to improve and enhance the bioproduction of biofuels. Improvement in the production of biofuels should ultimately make them more competitive in the marketplace.

\section{Methods}

\section{Bacterial cultures and medium}

To test butyrate/butyric acid production by various strains, a rich P2 medium containing $60 \mathrm{~g} \cdot \mathrm{L}^{-1}$ glucose, 
$3.6 \mathrm{~g} \cdot \mathrm{L}^{-1}$ yeast extract, $2.7 \mathrm{~g} \cdot \mathrm{L}^{-1}$ peptone, $3.2 \mathrm{~g} \cdot \mathrm{L}^{-1}$ $\mathrm{K}_{2} \mathrm{HPO}_{4}, 3.2 \mathrm{~g} \cdot \mathrm{L}^{-1} \mathrm{KH}_{2} \mathrm{PO}_{4}, 0.2 \mathrm{~g} \cdot \mathrm{L}^{-1} \mathrm{MgSO}_{4}, 0.2 \mathrm{~g} \cdot \mathrm{L}^{-1}$ $\mathrm{MnSO}_{4}, 0.02 \mathrm{~g} \cdot \mathrm{L}^{-1} \mathrm{FeSO}_{4}, 0.02 \mathrm{~g} \cdot \mathrm{L}^{-1} \mathrm{NaCl}, 1.5 \mathrm{~g} \cdot \mathrm{L}^{-1}$ yeast extract (Difco, Detroit, MI, USA), $2.5 \mathrm{~g} \cdot \mathrm{L}^{-1}$ ammonium acetate, $0.0005 \mathrm{~g} \cdot \mathrm{L}^{-1} \mathrm{p}$-aminobenzoate, $0.0005 \mathrm{~g} \cdot \mathrm{L}^{-1}$ thiamin, $0.00005 \mathrm{~g} \cdot \mathrm{L}^{-1}$ biotin and $35 \mu \mathrm{g} \cdot \mathrm{mL}^{-1}$ thiamphenicol was used. To test butyrate/butyric acid production from different substrates, the same rich P2 medium containing $30 \mathrm{~g} \cdot \mathrm{L}^{-1}$ of a different carbon source (gluconate, glucose, mannose, sorbitol, mannitol, xylose or glycerol) was used. Unless otherwise noted, the fermentation was carried out in serum bottles, each containing $40 \mathrm{~mL}$ of the medium and inoculated with $1 \%(\mathrm{v} / \mathrm{v})$ of an overnight culture in reinforced clostridial medium (Difco) at $37^{\circ} \mathrm{C}$ and $250 \mathrm{rpm}$. The $\mathrm{pH}$ was kept between 5.0 and 6.5 by adding $\mathrm{NaOH}$ solution twice a day.

\section{Experimental setup, irradiation and MTT assay}

The experiment was performed at the Cancer Therapy Terminal of the HIRF). The upgraded accelerator system of HIRFL consists of Sector Focus Cyclotron, Separated Sector Cyclotron, the CSRm and the experimental Cooling Storage Ring. High-energy ${ }^{12} \mathrm{C}^{6+}$ ions with energy of 207 $\mathrm{AMeV}$ and $162 \mathrm{AMeV}$ were extracted by CSRm. The energies of $68 \mathrm{AMeV}$ and $114 \mathrm{AMeV}$ were obtained by adding the absorbers (water) and calibrated by using the LISE program $^{a}$, and the corresponding uncertainty of the energies was no more than $0.22 \%$ [89-91]. The extraction time of the carbon ions (about $10^{6}$ to $10^{8}$ ions.pulse ${ }^{-1}$ ) was about $3 \mathrm{~s}$ and the priming dose 10 to $50 \mathrm{~Gy}$. Dose rates were up to $1.0 \mathrm{~Gy} \cdot \mathrm{min}^{-1}$. For irradiation experiments, strains cell were grown in flasks $\left(15 \mathrm{~cm}^{2}\right)$ to reach $90 \%$ confluence and they were completely filled with Dulbecco's modified Eagle's medium to avoid artifacts by irradiation through air layers [92]. The protocol is adapted from literature methods [93]. Briefly, Dulbecco's modified Eagle's medium was supplemented with $100 \mu \mathrm{L}$ of MTT reagent $\left(c=0.5 \mathrm{~g} \cdot \mathrm{L}^{-1}\right)$ to each well and incubated for $30 \mathrm{~min}$ at $37^{\circ} \mathrm{C}$. The MTT solution was then removed. After addition of $180 \mu \mathrm{L}$ of dimethyl sulfoxide, the plates were incubated for $15 \mathrm{~min}$ at $37^{\circ} \mathrm{C}$ to dissolve the formazan crystals [94]. Absorbance readings of dimethyl sulfoxide extracts were performed at $560 \mathrm{~nm}$ with reference of $690 \mathrm{~nm}$ using a Tecan Infinite F 200 microplate reader (Crailsheim, Germany). Treated cells were harvested the next day using trypsinization, counted and a specific number of strains cell (600 and 300 strains cell) were plated in petri dishes in triplicate for clonogenic assay. The multiple MTT assay was performed using 96-well-plates with 3,000 or 6,000 cells per well. The survival fraction was calculated from the following equation:

$$
\text { Survival }=2^{-\frac{t_{\text {delay }}}{t_{\text {doublingtime }}}}
$$

in which $t_{\text {doubling time }}$ is the time period required for a quantity of cells to double and $t_{\text {delay }}$ is the time period to reach specific absorption value of control versus irradiated cells.

\section{Biomass concentration and specific growth rate}

After irradiation, cultures were inoculated with $0.9 \%(\mathrm{v} / \mathrm{v})$ of nonsporulated preculture $\left(\mathrm{OD} 600_{\mathrm{nm}}=2\right.$ on various nutritional medium) and incubated at $37^{\circ} \mathrm{C}$ and $125 \mathrm{rpm}$ with CGM containing glucose in $1 \mathrm{~L}$ bottles. Growth was tracked by monitoring light scattering at $600_{\mathrm{nm}}$ with a SmartSpec $^{\mathrm{TM}} 3000$ spectrophotometer over a period of every $24 \mathrm{~h}$ for 5 days. Growth kinetics experiments were determined on a graph representing $\operatorname{Ln}\left(O D 600_{n m}\right)=f(t)$. Doubling times $(d)$ were calculated during the exponential phase according to the formula:

$$
n=\left(\operatorname{Ln}\left(O D t_{2}\right)-\operatorname{Ln}\left(O D t_{1}\right) / \operatorname{Ln}(2) \text { and } d=t_{2}-t_{1} / n\right.
$$

where $n$ represents the number of generations. Cultivation performance was in general judged by the yield of the butyrate/butyric acid production. As units, the yield per volume of cultivation broth (grams per 1,000 mL) and specific yield per biomass cell weight (grams per $1,000 \mathrm{~mL}$ ) were measured at the end of cultivation. For determination of specific productivity, the growth curve of the C. tyrobutyricum ATCC 25755 strains, using BDW as biomass, was integrated, yielding the biomass dry weight integral (BDWI).

$$
B D W I_{t 2}=B D W I_{t 1}+\left[\frac{B D W_{t 1}+B D W_{t 2}}{2}\left(t_{2}-t_{1}\right)\right]
$$

The BDW was determined following the protocol given by Wucherpfennig [95] with modifications. Culture samples $(10 \mathrm{~mL})$ were taken in $20 \mathrm{~mL}$ centrifuge tubes. The cells were measured gravimetrically by filtering (Nalgene 300-4100) a defined amount of biomass suspension through a pre-dried and pre-weighted suction filter (Filter Paper, Grade 392, Anugrah Niaga Mandiri, Jakarta, Indonesia). The filter was rinsed several times with deionized water to remove medium components from the biomass [96] and dried at $105^{\circ} \mathrm{C}$ to a constant weigh for $48 \mathrm{~h}$. The BDW concentration (grams per 1,000 mL) was calculated as the difference between the weight of the filter with and without dried biomass divided by the sample volume. The BDW data points from the logarithmic growth phase were plotted on a semi-log graph to locate the period in which the culture experienced the fastest growth. These points were then used in the following equation:

$$
\mu_{\max }\left(\frac{1}{h}\right)=\frac{\Delta \ln B D W}{\Delta T}=\frac{\ln \left(B D W_{t 2}-B D W_{t 1}\right)}{T_{2}-T_{1}}
$$


where BDW was measured in grams per $1,000 \mathrm{~mL}$ and time in hours. $\mathrm{BDW}_{\mathrm{t} 1}$ is the first point during the fastest logarithmic growth period and $\mathrm{BDW}_{\mathrm{t} 2}$ is the last point. $\mathrm{T}_{1}$ and $\mathrm{T}_{2}$ are described similarly.

\section{Analysis by SDS-PAGE}

Protein samples for SDS-PAGE were prepared from the cell extract after sonication and centrifugation. The strains cell extract $(15 \mathrm{~mL})$ was concentrated using four volumes of acetone $(60 \mathrm{~mL})$ to precipitate protein at $-20^{\circ} \mathrm{C}$ overnight, and re-dissolved in $3.5 \mathrm{~mL}$ of $25 \mathrm{mM}$ Tris- $\mathrm{HCl}$ buffer ( $\mathrm{pH}$ 7.2), following the standard protocol (Bio-Rad, Shanghai, China). Protein samples, $25 \mu \mathrm{g}$ per well, were loaded into $12.5 \%$ SDS-PAGE gel and run at $100 \mathrm{~V}$ for $2.5 \mathrm{~h}$ with PROTEAN II xi Cell (Bio-Rad) and stained following the instructions of the manufacturer [97-99].

\section{Cell extracts and enzyme assays}

The strains were cultivated in the same rich P2 medium $(100 \mathrm{~mL})$ at $37^{\circ} \mathrm{C}$ to the exponential phase $\left(\mathrm{OD}_{600}=\right.$ $-1.5)$. The cells were harvested, washed and suspended in $5 \mathrm{~mL}$ of $25 \mathrm{mM}$ Tris- $\mathrm{HCl}$ (pH 7.4) [100]. The suspension was then sonicated, and cell debris was removed by centrifugation. The protein content of extracts was determined by the Bradford method with bovine serum albumin as the standard [101]. All these were done under ambient conditions. For the hydrogenase activity assay, cells were suspended in $150 \mathrm{mM}$ Tris- $\mathrm{HCl}$ buffer (pH 7.4), which also contained 15 mMATP, $10 \mathrm{mM}$ $\mathrm{MgCl}_{2}$ and 6\% (w/v) hydroxylamine hydrochloride (neutralized with potassium hydroxide), and lysed at $37^{\circ} \mathrm{C}$ for $30 \mathrm{~min}\left(100 \mu \mathrm{g} \cdot \mathrm{mL}^{-1}\right.$; Sigma, Shanghai, China) [102-104]. The reaction was initiated by adding cell extract and stopped after $15 \mathrm{~min}$ by adding $10 \%(\mathrm{w} / \mathrm{v})$ icecold trichloroacetic acid. Color was then developed by adding $2.5 \%(\mathrm{w} / \mathrm{v}) \mathrm{FeCl}_{3}$ in $2.0 \mathrm{~N} \mathrm{HCl}$, and the absorbance at $540 \mathrm{~nm}$ was measured $[105,106]$. One unit of enzyme activity is defined as the amount of enzyme that produces $1 \mu \mathrm{mol}$ of hydroxamic acid per min. Phosphotransacetylase and phosphotransbutyrylase were assayed with $0.2 \mathrm{mM}$ acetyl-CoA and butyryl-CoA as the enzyme substrates, respectively, in $0.1 \mathrm{M}$ potassium phosphate buffer ( $\mathrm{pH}$ 7.4) following previous methods [107,108]. The enzyme activity was monitored by following the liberation of CoA at $405 \mathrm{~nm}$, and one unit of enzyme was defined as the amount of enzyme converting $1 \mu \mathrm{mol}$ of acetyl-CoA or butyryl-CoA per minute. The specific activities of AK, BK, PTA and PTB were defined as the units of enzyme activity per milligram of total protein.

\section{Fermentation after irradiation}

After irradiation, $100 \mathrm{~mL}$ of cell suspension prepared in serum bottles was inoculated into the fermentor and then allowed to grow for 3 days at $37^{\circ} \mathrm{C}$, agitated at $150 \mathrm{rpm}$, and $\mathrm{pH}$ controlled at 6.0 by adding $\mathrm{NH}_{4} \mathrm{OH}$. After about 33 to $42 \mathrm{~h}$ of continuous circulation, most of the cells were immobilized and no change in cell density in the medium could be identified. The spent medium in the fermentor was then replaced with fresh medium, and the recirculation rate increased to $120 \mathrm{~mL} \cdot \mathrm{min}^{-1}$ for new batch fermentation. For the main fermentation, CGM was used, containing 25 to 100 g glucose, $0.65 \mathrm{~g} \mathrm{~K}_{2} \mathrm{HPO}_{4}$, $0.65 \mathrm{~g} \mathrm{KH}_{2} \mathrm{PO}_{4}, 0.6 \mathrm{~g} \mathrm{MgSO} 4 \cdot 7 \mathrm{H}_{2} \mathrm{O}, 0.02 \mathrm{~g} \mathrm{MnSO}_{4} \cdot 7 \mathrm{H}_{2} \mathrm{O}$, $0.02 \mathrm{~g} \mathrm{FeSO}_{4} \cdot 7 \mathrm{H}_{2} \mathrm{O}, 1.5 \mathrm{~g} \mathrm{NaCl}, 2.5 \mathrm{~g}$ asparagines, $6 \mathrm{~g}$ yeast extract and $1.5 \mathrm{~g}\left(\mathrm{NH}_{4}\right)_{2} \mathrm{SO}_{4}$ in $1.5 \mathrm{~L}$ of distilled water. Modified reinforced clostridial medium (Difco) was used for pre-culture and solid culture and contained the following ingredients per liter of distilled water: $15 \mathrm{~g}$ glucose, $10 \mathrm{~g}$ tryptose, $10 \mathrm{~g}$ beef extract, $3 \mathrm{~g}$ yeast extract, $5 \mathrm{~g}$ $\mathrm{NaCl}, 1 \mathrm{~g}$ soluble starch, $0.5 \mathrm{~g}$ cysteine hydrochloride and $3 \mathrm{~g}$ sodium acetate in $15 \mathrm{~g} \cdot \mathrm{L}^{-1}$ of agar. After C. tyrobutyricum 25755 was pre-cultured using reinforced clostridial medium at $37^{\circ} \mathrm{C}$ and $\mathrm{pH} 6.0$ under anaerobic conditions, the grown cells were inoculated $(10 \%, v / v)$ into CGM containing glucose or pre-treated brown algae substituted for glucose. The main fermentation was conducted in a 5 L stirred-tank fermentor (BE Marubishi, Pathumthani, Thailand) with a working volume of $1.5 \mathrm{~L}$, and $\mathrm{pH}$ was controlled at 6.0 using $3 \mathrm{M} \mathrm{NaOH}$ solutions. Anaerobiosis was reached by sparging the fermentor medium with $\mathrm{N}_{2}$ gas for 5 to $10 \mathrm{~min}$ before inoculation and constantly stirred at $150 \mathrm{rpm}$ during cultivation. A detailed description of the reactor construction has been given elsewhere [54].

\section{Analytical methods}

Cell density was analyzed by measuring the OD of the cell suspension at $600 \mathrm{~nm}$ using a spectrophotometer (Thermo Electron Scientific Instruments Corp., Madison, WI USA) with a conversion of $0.42 \mathrm{~g} \cdot \mathrm{L}^{-1}$ of dry cell weight per OD unit. Dry weight of immobilized-cell biomass was determined by centrifugation of the fermentation broth at $10,000 \mathrm{~g}$ for $10 \mathrm{~min}$, washing the sediment with distilled water, and drying at $110^{\circ} \mathrm{C}$ overnight. Butyric acid and acetic acid were analyzed with a GC-2014 Shimadzu gas chromatograph (Shimadzu, Columbia, MD, USA) equipped with a flame ionization detector and a $30.0 \mathrm{~m}$ fused silica column $(0.25 \mathrm{~mm}$ film thickness and $0.25 \mathrm{~mm}$ ID, Stabilwax-DA). The gas chromatograph was operated at an injection temperature of $200^{\circ} \mathrm{C}$ with $1 \mu \mathrm{L}$ of sample injected with the AOC-20i Shimadzu auto injector. Column temperature was held at $80^{\circ} \mathrm{C}$ for $3 \mathrm{~min}$, raised to $150^{\circ} \mathrm{C}$ at $30^{\circ} \mathrm{C} \mathrm{m^{-1 }}$, and then held at $150^{\circ} \mathrm{C}$ for $3.7 \mathrm{~min}$. A high performance liquid chromatography system was used to analyze the carbonhydrate compounds, including glucose, fructose and sucrose in the fermentation broth. The high performance liquid chromatography system 
consisted of an automatic injector (Agilent Technologies Inc, Beijing, China), a pump (Agilent 1100, G1311A), a Zorbax carbohydrate analysis column $(250 \mathrm{~mm} \times 4.6 \mathrm{~mm}$, $5 \mu \mathrm{m}$; Agilent, USA), a column oven at $30^{\circ} \mathrm{C}$ (Agilent 1100, G1316A), and a refractive index detector (Agilent 1100, G1362A). The mobile phase was ethyl nitrile (ethyl nitrile $/$ water $=75: 25)$ at a flow rate of $1.5 \mathrm{~mL} \cdot \mathrm{min}^{-1}$.

\section{Endnote}

${ }^{a}$ The LISE program is designed to predict the intensity and purity of radioactive ion beams produced by inflight separators. It also facilitates the tuning of experiments where its results can be quickly compared to on-line data.

\section{Abbreviations \\ AK: acetate kinase; BDW: biomass dry weight; BK: butyrate kinase; CGM: clostridial growth medium; CoA: coenzyme A; CSRm: Main Cooling Storage Ring; HIRFL: Heavy ion research facility in Lanzhou; MTT: 3-(4,5-dimethylthiazol-2-yl)-2,5-diphenyltetrazolium bromide; OD: optical density; PTA: phosphotransacetylase; PTB: phosphotransbutyrylase.}

\section{Competing interests}

The authors declare that they have no competing interests.

\section{Authors' contributions}

XZ drafted and reviewed the work, revised it critically for important intellectual content and gave final approval of the version to be published; $\mathrm{XHL}, \mathrm{XHL}$ and ZJX participated in the study design and coordination and were involved in revising the manuscript critically for important intellectual contents; JRX, MRZ, LW and WYD executed the experimental work and data analysis, executed the experimental work and drafted the manuscript. JPL assisted in the experimental design and was involved in revising the manuscript critically for important intellectual content. All authors read and approved the final version of the manuscript.

\section{Acknowledgements}

This study was supported by the National Natural Science Foundation of China (11105193), the China Postdoctoral Science Foundation (2011 M501497), Project supported by the Postdoctoral Foundation of Institute of Modern Physics, Chinese Academy of Sciences, China (Y161060ZYO) and the Hundred Talent Program of the Chinese Academy of Science (O861010ZYO)

The principal author gratefully acknowledges the Project Sponsored by the Scientific Research Foundation for the Returned Overseas Chinese Scholars, State Education Ministry and the support of K.C. Wong Education Foundation, Hong Kong.

\section{Author details}

'Institute of Modern Physics, Chinese Academy of Sciences, 509 Nanchang Road, Lanzhou, Gansu 730000, PR China. ${ }^{2}$ China Pharmaceutical University, \#24 Tongjiaxiang, Nanjing 210009, PR China.

Received: 1 September 2013 Accepted: 3 February 2014 Published: 18 February 2014

\section{References}

1. Hoelzle R: Genetic improvement of Clostridium tyrobutyricum for butanol production by insertion of adhE from Clostridium acetobutylicum, Honors Thesis. Department of Chemical and Biomolecular Engineering: The Ohio State University; 2010.

2. Chen JS: Alcohol dehydrogenase: multiplicity and relatedness in the solvent-producing clostridia. FEMS Microbiol Rev 1995, 17(3):263-273.

3. Dwidar M, Park JY, Mitchell RJ, Sang BI: The future of butyric acid in industry. ScientificWorldJournal 2012, 2012:471417.

4. Song H, Eom MH, Lee S, Lee J, Cho JH, Seung D: Modeling of batch experimental kinetics and application to fed-batch fermentation of
Clostridium tyrobutyricum for enhanced butyric acid production. Biochem Eng J 2010, 53(1):71-76.

5. Jiang L, Wang J, Liang S, Cai J, Xu Z, Cen P, Yang S, Li S: Enhanced butyric acid tolerance and bioproduction by Clostridium tyrobutyricum immobilized in a fibrous bed bioreactor. Biotechnol Bioeng 2011, 108(1):31-40.

6. Zigov J, Turdik E: Advances in biotechnological production of butyric acid. J Ind Microbiol Biot 2000, 24(3):153-160.

7. Huang J, Cai J, Wang J, Zhu XC, Huang L, Yang ST, Xu Z: Efficient production of butyric acid from Jerusalem artichoke by immobilized Clostridium tyrobutyricum in a fibrous-bed bioreactor. Bioresour Technol 2011, 102(4):3923-3926.

8. Wang X, Maegawa T, Karasawa T, Ozaki E, Nakamura S: Clostridium sardiniense Prvot 1938 and Clostridium absonum Nakamura et al. 1973 are heterotypic synonyms: evidence from phylogenetic analyses of phospholipase $\mathrm{C}$ and $16 \mathrm{~S}$ rRNA sequences, and DNA relatedness. Int J Syst Evol Microbiol 2005, 55(Pt3):1193-1197.

9. Ahmed A, Lewis RS: Fermentation of biomass-generated synthesis gas: effects of nitric oxide. Biotechnol Bioeng 2007, 97(5):1080-1086.

10. Clark GC, Briggs DC, Karasawa T, Wang X, Cole AR, Maegawa T, Jayasekera PN, Naylor CE, Miller J, Moss DS, Nakamura S, Basak AK, Titball RW: Clostridium absonum alpha-toxin: new insights into clostridial phospholipase C substrate binding and specificity. J Mol Biol 2003 , 333(4):759-769.

11. Liu XG, Zhu Y, Yang ST: Butyric acid and hydrogen production by Clostridium tyrobutyricum ATCC 25755 and mutants. Enzyme Microb Tech 2006, 38(3-4):521-528.

12. Collins MD, Lawson PA, Willems A, Cordoba JJ, Fernandez-Garayzabal J, Garcia P, Cai J, Hippe H, Farrow JA: The phylogeny of the genus Clostridium: proposal of five new genera and eleven new species combinations. Int J Syst Bacteriol 1994, 44(4):812-826.

13. Cato EP, Hash DE, Holdeman LV, Moore WE: Electrophoretic study of Clostridium species. J Clin Microbiol 1982, 15(4):688-702.

14. Skerman VDB, McGowan V, Sneath PHA: In Approved Lists of Bacterial Names (Amended). Edited by Skerman VBD, McGowan V, Sneath PHA. Washington (DC): ASM Press; 1989.

15. Hayase M, Mitsui N, Tamai K, Nakamura S, Nishida S: Isolation of Clostridium absonum and its cultural and biochemical properties. Infect Immun 1974, $9(1): 15-19$

16. Nakamura S, Shimamura T, Hayase M, Nishida S: Numerical taxonomy of Saccharolytic clostridia, particularly Clostridium perfringens-like strains: descriptions of Clostridium absonum sp. n. and Clostridium paraperfringens. Int J Syst Bacteriol 1973, 23(4):419-429.

17. Xu D, Lewis RS: Syngas fermentation to biofuels: effects of ammonia impurity in raw syngas on hydrogenase activity. Biomass Bioenergy 2012, 45:303-310.

18. Zhu Y, Liu X, Yang ST: Construction and characterization of pta gene-deleted mutant of Clostridium tyrobutyricum for enhanced butyric acid fermentation. Biotechnol Bioeng 2005, 90(2):154-166

19. Johnson JL, Francis BS: Taxonomy of the Clostridia: ribosomal ribonucleic acid homologies among the species. J Gen Microbio/ 1975, 88(2):229-244.

20. Jiang L, Wang JF, Liang SZ, Cai J, Xu ZN: Control and optimization of Clostridium tyrobutyricum ATCC 25755 adhesion into fibrous matrix in a fibrous bed bioreactor. Appl Biochem Biotechnol 2011, 165:98-108.

21. Davey ME, O'toole GA: Microbial biofilms: from ecology to molecular genetics. Microbiol Mol Biol Rev 2000, 64(4):847-867.

22. Ferrandi EE, Bertolesi GM, Polentini F, Negri A, Riva S, Monti D: In search of sustainable chemical processes: cloning, recombinant expression, and functional characterization of the 7alpha- and 7beta-hydroxysteroid dehydrogenases from Clostridium absonum. Appl Microbiol Biotechnol 2011, 95(5):1221-1233.

23. Tashiro Y, Shinto H, Hayashi M, Baba S, Kobayashi G, Sonomoto K: Novel high-efficient butanol production from butyrate by non-growing Clostridium saccharoperbutylacetonicum N1-4 (ATCC 13564) with methyl viologen. J Bioscie Bioeng 2007, 104:238-240

24. Song JH, Ventura JRS, Lee CH, Jahng D: Butyric acid production from brown algae using Clostridium tyrobutyricum ATCC 25755. Biotechnol Bioproc E 2011, 16(1):42-49.

25. Rogers P, Chen JS, Zidwick MJ: Organic acid and solvent production. Proc Natl Acad Sci USA 2006, 3:511-755.

26. Zhu Y, Yang ST: Effect of $\mathrm{pH}$ on metabolic pathway shift in fermentation of xylose by Clostridium tyrobutyricum. J Biotechnol 2004, 110(2):143-157. 
27. Malcaa J, Freireb F: Renewability and lifecycle energy efficiency of bioethanol and bio-ethyl tertiary butyl ether (bioETBE): assessing the implications of allocation. Energy 2006, 31(15):3362-3380.

28. Chavanne X, Frangi JP: Comparison of the energy efficiency to produce agroethanol between various industries and processes: the transport stage. Biomass Bioenerg 2011, 35(19):4075-4091.

29. Wei D, Liu XG, Yang ST: Butyric acid production from sugarcane bagasse hydrolysate by Clostridium tyrobutyricum immobilized in a fibrous-bed bioreactor. Bioresour Technol 2013, 129:553-560.

30. Chang JJ, Chou CH, Ho CY, Chen WN, Lay JJ, Huang CC: Syntrophic coculture of aerobic Bacillusand anaerobic Clostridium for biofuels and bio-hydrogen production. Int J Hydrogen Energ 2008, 33(19):5137-5146.

31. Tran HTM, Cheirsilp B, Hodgson B, Umsakulc K: Potential use of Bacillus subtilisin a co-culture with Clostridium butylicum for acetone-butanolethanol production from cassava starch. Biochem Eng J 2010, 48(2):260-267.

32. Quintana N, Van de Rhee FVKMD, Voshol GP, Verpoorte R: Renewable energy from cyanobacteria: energy production optimization by metabolic pathway engineering. App/ Microbiol Biotechnol 2011, 91(3):471-490

33. Naika SN, Goudb W, Rout PK, Dalai AK: Production of first and second generation biofuels: a comprehensive review. Renew Sust Energ Rev 2009, 14:578-597.

34. Antoni D, Zverlov W, Schwarz WH: Biofuels from microbes. App Microbiol Biot 2007, 77(1):23-35.

35. Wu ZT, Yang ST: Extractive fermentation for butyric acid production from glucose by Clostridium tyrobutyricum. Biotechnol Bioeng 2003, 82(1):93-102.

36. Zhang CH, Yang H, Yang FX, Ma YJ: Current progress on butyric acid production by fermentation. Curr Microbiol 2009, 59(6):656-663.

37. Tracy BP, Jones SW, Fast AG, Indurthi DC, Papoutsakis ET: Clostridia: the importance of their exceptional substrate and metabolite diversity for biofuel and biorefinery applications. Curr Opin Biotech 2012, 23(3):364-381.

38. Filho MV, Araujo C, Bonf A, Porto W: Chemistry based on renewable raw materials: perspectives for a sugar canebased biorefinery. Enzyme Res 2011, 2011:654596

39. Serrano-Ruiz JC, West RM, Dumesic JA: Catalytic conversion of renewable biomass resources to fuels and chemicals. Annu Rev Chem Biomol Eng 2010, 1:79-100.

40. Lee SY, Park JH, Jang SH, Nielsen LK, Kim J, Jung KS: Fermentative butanol production by clostridia. Biotechnol Bioeng 2008, 101(2):209-228.

41. Shinto H, Tashiro Y, Kobayashi G, Sekiguchi T, Hanai T, Kuriya Y, Okamoto M, Sonomoto K: Kinetic study of substrate dependency for higher butanol production in acetone-butanol-ethanol fermentation. Process Biochem 2008, 43(12):1452-1461.

42. Jang YS, Lee JY, Lee J, Park JH, Ae Im J, Eom MH, Lee J, Lee SH, Song H Cho JH, Seung DY, Lee SY: Enhanced butanol production obtained by reinforcing the direct butanol-forming route in Clostridium acetobutylicum. MBio 2012, 3(5):e00314-12.

43. Ltke-Eversloh T, Bahl H: Metabolic engineering of Clostridium acetobutylicum: recent advances to improve butanol production. Curr Opin Biotechnol 2012, 22(5):634-647.

44. Lehmann D, Hnicke D, Ehrenreich A, Schmidt M, Weuster-Botz D, Bahl H, Ltke-Eversloh T: Modifying the product pattern of Clostridium acetobutylicum: physiological effects of disrupting the acetate and acetone formation pathways. Appl Microbiol Biotechnol 2012, 94(3):743-754.

45. Chong ML, Abdul Rahima R, Shirai Y, Ali Hassan M: Biohydrogen production by Clostridium butyricum EB6 from palm oil mill effluent Int J Hydrogen Energ 2009, 34(2):764-771.

46. Lin PY, Whang LM, Wu YR, Ren WJ, Hsiao CJ, Li SL, Chang JC: Biological hydrogen production of the genus Clostridium: metabolic study and mathematical model simulation. Int J Hydrogen Energ 2007, 32(12):1728-1735.

47. Calusinska M, Happe T, Joris B, Wilmotte A: The surprising diversity of clostridial hydrogenases: a comparative genomic perspective. Microbiology 2010, 156:1575-1588.

48. Liu XG, Zhu Y, Yang ST: Construction and characterization of ack deleted mutant of Clostridium tyrobutyricum for enhanced butyric acid and hydrogen production. Biotechnol Progr 2008, 22(5):1265-1275.

49. Jiang L, Wang JF, Liang SZ, Wang XN, Cen P, Xu ZN: Butyric acid fermentation in a fibrous bed bioreactor with immobilized Clostridium tyrobutyricum from cane molasses. Bioresource Technol 2009, 100(13):3403-3409.
50. Xu Z, Jiang L: 3.20-butyric acid. Comprehensive Biotechnology 2011, 3:207-215.

51. Zhu Y, Wu Z, Yang ST: Butyric acid production from acid hydrolysate of corn fiber by Clostridium tyrobutyricum in a fibrous-bed bioreactor. Process Biochem 2002, 38(5):657-666.

52. Zigova J, Sturdik E, Vandak D, Schlosser S: Butyric acid production by Clostridium butyricum with integrated extraction and pertraction. Process Biochem 1999, 34(8):835-844.

53. Vandak D, Zigova J, Sturdik E, Schlosser S: Evaluation of solvent and $\mathrm{pH}$ for extractive fermentation of butyric acid. Process Biochem 1997, 32(3):245-251.

54. Zhu Y, Yang ST: Adaptation of Clostridium tyrobutyricum for enhanced tolerance to butyric acid in a fibrous-bed bioreactor. Biotechnol Prog 2003, 19(2):365-372.

55. Jo JH, Jeon CO, Lee SY, Lee DS, Parke JM: Molecular characterization and homologous overexpression of [FeFe]-hydrogenase in Clostridium tyrobutyricum JM1. Int J Hydrogen Energ 2010, 35(3):1065-1073.

56. Sang Bl, Mitchell RJ, Kim JS, Jeon BS: Continuous hydrogen and butyric acid fermentation by immobilized Clostridium tyrobutyricum ATCC 25755 effects of the glucose concentration and hydraulic retention time. Bioresour Technol 2009, 100(21):53.

57. Jiang L, Cai J, Wang J, Liang S, XU Z, Yang ST: Phosphoenolpyruvatedependent phosphorylation of sucrose by Clostridium tyrobutyricum ZJU 8235: evidence for the phosphotransferase transport system. Bioresour Technol 2010, 101(1):304-309.

58. Jiang L, Wang J, Liang S, Wang X, Cen P, Xu Z: Production of butyric acid from glucose and xylose with immobilized cells of Clostridium tyrobutyricum in a fibrous-bed bioreactor. Appl Biochem Biotechnol 2010, 160(2):350-359.

59. Bisht D, Yadav SK, Darmwal NS: Enhanced production of extracellular alkaline lipase by an improved strain of pseudomonas aeruginosa MTCC 10,055. Am J Applied Sci 2012, 9(2):158-162.

60. Peano C, Tal A, Corti G, Pasanisi D, Durante M, Mita G, Bicciato S, De Bellis G, Alifano P: Comparative genomics and transcriptional profiles of Saccharopolyspora erythraea NRRL 2338 and a classically improved erythromycin over-producing strain. Microb Cell Fact 2012, 11:32

61. Nevoigt E: Progress in metabolic engineering of saccharomyces cerevisiae. Microbiol Mol Biol Rev 2008, 72(3):379-412

62. Schardt D, Elsasser T, Schulz-Ertner D: Heavy-ion tumor therapy: physical and radiobiological benefits. Rev Mod Phys 2010, 82:383-425.

63. Hawkins RB: A statistical theory of cell killing by radiation of varying linear energy transfer. Radiat Res 1944, 140:366-374.

64. McCready S, Muller JA, Boubriak I, Berquist BR, DasSarma S: UV irradiation induces homologous recombination genes in the model archaeon, Halobacterium sp. NRC-1. Saline Systems 2055, 4:1-3.

65. Kase Y, Kanai T, Matsufuji N, Furusawa Y, Elssser T, Scholz M: Biophysical calculation of cell survival probabilities using amorphous track structure models for heavy-ion irradiation. Phys Med Biol 2008, 7:37-59.

66. Choi JMD, Kang JOMD: Basics of particle therapy II: relative biological effectiveness. Radiat Oncol J 2012, 30:1-13.

67. Ito A, Nakano H, Kusano Y, Hirayama R, Furusawa Y, Murayama C, Mori T, Katsumura YSK: Contribution of indirect action to radiation-induced mammalian cell inactivation: dependence on photon energy and heavy-ion LET. Radiat Res 2006, 165:703-712.

68. DeVeaux LC, Muller JA, Smith J, Petrisko J, Wells SD, Pand D: Extremely radiation-resistant mutants of a halophilic archaeon with increased single-stranded DNA-binding protein (rpa) gene expression. Radiat Res 2007, 168:507-514

69. Munshi MK, Hossain MF, Huque R, Rahman M, Khatun A, Islam M, Hossain MA: Effect of gamma-ray induced mutant strains of Aspergillus niger on citric acid fermentation using molasses and jackfruit based medium. Acad J Nutr 2012, 1:19-24.

70. Sato T, Watanabe R, Kase Y: Analysis of cell-survival fractions for heavy-ion irradiations based on microdosimetric kinetic model implemented in the particle and heavy ion transport code system. Radiat Prot Dosim 2011, 143:491-496.

71. Vandersickel V, Depuydt J, Van Bockstaele B, Perletti G, Philippe J, Thierens $H$, Vral A: Early increase of radiation-induced $\gamma \mathrm{H} 2 \mathrm{AX}$ foci in a human Ku70/80 knockdown cell line characterized by an enhanced radiosensitivity. J Radiat Res 2010, 51:633-641.

72. Tangney M, Mitchell WJ: Characterisation of a glucose phosphotransferase system in Clostridium acetobutylicum ATCC 824. Appl Microbiol Biotechnol 2007, 74(2):398-405. 
73. Janssen H, Döring C, Ehrenreich A, Voigt B, Hecker M, Bahl H, Fischer RJ: A proteomic and transcriptional view of acidogenesis and solventogenesis in Clostridium acetobutylicum in a chemostat culture. Appl Microbiol Biotechnol 2010, 87(6):2209-2226.

74. de Mattos MJT, de Boer JP, Zoutberg GR, Neijssel OM: Metabolic shift analysis at high cell densities. FEMS Microbiol Rev 1994, 14(1):21-28.

75. Jones DT, Woods DR: Acetone-butanol fermentation revisited. Microbiol Rev 1986, 50(40):484-524.

76. Andersch W, Bahl H, Gottschalk G: Level of enzymes involved in acetate, butyrate, acetone and butanol formation by Clostridium acetobutylicum Appl Microbiol Biotechnol 1983, 18(6):327-332.

77. Boynton ZL, Bennett GN, Rudolph FB: Cloning, sequencing, and expression of genes encoding phosphotransacetylase and acetate kinase from Clostridium acetobutylicum ATCC 824. Appl Environ Microbiol 1996, 62:2758-2766

78. Michel-Savin D, Marchal R, Vandecasteele JP: Control of the selectivity of butyric acid production of Clostridium tyrobutyricum. Appl Microbiol Biotechnol 1990, 32:387-392.

79. Jaros AM, Rova U, Berglund KA: Acetate adaptation of Clostridia tyrobutyricum for improved fermentation production of butyrate. Springer Plus 2013, 3:47.

80. Kovrov-Kovar K, Egli T: Growth kinetics of suspended microbial cells: from single-substrate-controlled growth to mixed-substrate kinetics. Microbiol Mol Biol Rev 1998, 62(3):646-666.

81. Meeuwse $P$, Akbari $P$, Rinzema A: Modeling growth, lipid accumulation and lipid turnover in submerged batch cultures of Umbelopsis isabellina. Bioprocess Biosyst Eng 2012, 35(4):519-603.

82. Okpokwasili GC, Nweke CO: Microbial growth and substrate utilization kinetics. Afr J Biotechnol 2005, 5(4):305-317.

83. Lynd LR, Weimer PJ, Pretorius IS: Microbial cellulose utilization: fundamentals and biotechnology. Microbiol Mol Biol Rev 2002, 66(3):506-577

84. Van der Meulen R, Avonts L, de Vuyst L: Short fractions of oligofructose are preferentially metabolized by bifidobac-terium animalis DN-173010. Appl Environ Microbiol 2004, 70(4):1923-1930.

85. Michel-Savin D, Marchal R, Vandecasteele JP: Butyrate production in continuous culture of clostridium tyrobutyricum: effect of end-product inhibition. Appl Microbiol Biotechnol 1990, 33(2):127-131.

86. Michel-Savin D, Marchal R, Vandecasteele JP: Control of the selectivity of butyric acid production and improvement of fermentation performance with Clostridium tyrobutyricum. Appl Microbiol Biotechnol 1990, 32(4):387-392

87. Ferras E, Minier M, Goma G: Acetonobutylic fermentation: improvement of performances by coupling continuous fermentation and ultrafiltration. Biotechnol Bioeng 1986, 28(4):523-533.

88. Du JJ, McGraw A, Lorenz N, Beitle RR, Clausen EC, Hestekin JA: Continuous fermentation of Clostridium tyrobutyricum with partial cell recycle as a long-term strategy for butyric acid production. Energies 2012, 5:2835-2848.

89. Lei Y, Zhao Y, Cheng R, Zhou X, Sun Y, Wang X, Xu G, Wang Y, Li S, Xiao G. Fluorescence emission from $\mathrm{CsI}(\mathrm{TI})$ crystal induced by high-energy carbon ions. Opt Mater 2013, 35:1179-1183.

90. Yanga $Y Y$, Wang JS, Wang $Q$, Ma JB, Huang MR, Han JP, Ma P, Jin SL, Bai Z, Hu Q, Jin L, Chen JB, Wada R, Sun ZY, Chen RF, Zhang XY, Hu ZG, Yuan XH, Cao XG, Xu ZG, Xu SW, Zhen X, Chen ZQ, Chen Z, Chen SZ, Du CM, Duan $L M, F u$ F, Gou BX, Hu J, et al: A method for the measurement of elastic scattering angular distribution at HIRFL-RIBLL. NuCl Instrum Meth A 2013 701:1-6

91. Zhou X, Xin ZJ, Lu XH, Yang XP, Zhao MR, Wang L, Liang JP: High efficiency degradation crude oil by a novel mutant irradiated from Dietzia strain by ${ }^{12} \mathrm{C}^{6+}$ heavy ion using response surface methodology. Bioresour Technol 2013, 137:386-393.

92. Zhou X, Xie JR, Tao L, Xin ZJ, Zhao FW, Lu XH, Zhao MR, Wang L, Liang JP: The effect of microdosimetric ${ }^{12} \mathrm{C}^{6+}$ heavy ion irradiation and $\mathrm{Mg}^{2+}$ on canthaxanthin production in a novel strain of Dietzia natronolimnaea. BMC Microbiol 2013, 13(1):213.

93. Price $P, M c M i l l a n T J$ : Use of the tetrazolium assay in measuring the response of human tumor cells to ionizing radiation. Cancer Res 1990, 50:1392-1396.
94. Buch $K$, Peters T, Nawroth T, Snger M, Schmidberger $H$, Langguth P: Determination of cell survival after irradiation via clonogenic assay versus multiple MTT assay - a comparative study. Radiat Oncol 2012, 7:1.

95. Wucherpfennig T, Hestler T, Krull R: Morphology engineering-osmolality and its effect on Aspergillus niger morphology and productivity. Microb Cell Fact 2011, 10:58

96. Yang SJ, Kataeva I, Adams MW: Efficient degradation of lignocellulosic plant biomass, without pretreatment, by the thermophilic anaerobe "Anaerocellum thermophilum" DSM 6725. Appl Environ Microbiol 2009 74(14):4762-4769.

97. Dwidar M, Kim S, Jeon BS, Um Y, Mitchell RJ, Sang BI: Co-culturing a novel Bacillus strain with Clostridium tyrobutyricum ATCC 25755 to produce butyric acid from sucrose. Biotechnol Biofuels 2013, 6(1):35.

98. Roach DR, Khatibi PA, Bischoff KM, Hughes SR, Donovan DM: Bacteriophage-encoded lytic enzymes control growth of contaminating Lactobacillus found in fuel ethanol fermentations. Biotechnol Biofuels 2013, 6(1):20.

99. Herpoel-Gimbert I, Margeot A, Dolla A, Jan G, Molle D, Lignon S, Mathis H, Sigoillot JC, Monot F, Asther M: Comparative secretome analyses of two Trichoderma reesei RUT-C30 and CL847 hypersecretory strains. Biotechnol Biofuels 2008, 1(1):18.

100. Korman TP, Sahachartsiri B, Charbonneau DM, Huang GL, Beauregard M, Bowie JU: Dieselzymes: development of a stable and methanol tolerant lipase for biodiesel production by directed evolution. Biotechnol Biofuels 2013, 6(1):70.

101. Xu C, Huang R, Teng L, Wang D, Hemme CL, Borovok I, He Q, Lamed R, Bayer EA, Zhou J, Xu J: Structure and regulation of the cellulose degradome in Clostridium cellulolyticum. Biotechnol Biofuels 2013, 6(1):73.

102. Liu J, Chen L, Wang J, Qiao J, Zhang W: Proteomic analysis reveals resistance mechanism against biofuel hexane in Synechocystis sp. PCC 6803. Biotechnol Biofuels 2012, 5(1):68.

103. Masset J, Calusinska M, Hamilton C, Hiligsmann S, Joris B, Wilmotte A, Thonart $P$ : Fermentative hydrogen production from glucose and starch using pure strains and artificial co-cultures of Clostridium spp. Biotechnol Biofuels 2012, 5(1):35.

104. Tartar A, Wheeler MM, Zhou X, Coy MR, Boucias DG, Scharf ME: Parallel metatranscriptome analyses of host and symbiont gene expression in the gut of the termite Reticulitermes flavipes. Biotechnol Biofuels 2009, 2:25.

105. Pyne ME, Moo-Young M, Chung DA, Chou CP: Development of an electrotransformation protocol for genetic manipulation of Clostridium pasteurianum. Biotechnol Biofuels 2013, 6(1):50.

106. Currie DH, Herring CD, Guss AM, Olson DG, Hogsett DA, Lynd LR: Functional heterologous expression of an engineered full length CipA from Clostridium thermocellum in Thermoanaerobacterium saccharolyticum. Biotechnol Biofuels 2013, 6(1):32.

107. Branduardi P, Longo V, Berterame NM, Rossi G, Porro D: A novel pathway to produce butanol and isobutanol in Saccha-romyces cerevisiae. Biotechnol Biofuels 2013, 6(1):68

108. Dai Z, Dong H, Zhu Y, Zhang Y, Li Y, Ma Y: Introducing a single secondary alcohol dehydrogenase into butanol-tolerant Clostridium acetobutylicum Rh8 switches ABE fermentation to high level IBE fermentation. Biotechnol Biofuels 2012, 5(1):44

doi:10.1186/1754-6834-7-22

Cite this article as: Zhou et al:: Radiation induces acid tolerance of Clostridium tyrobutyricum and enhances bioproduction of butyric acid through a metabolic switch. Biotechnology for Biofuels 2014 7:22. 